\title{
Snf1 cooperates with the CWI MAPK pathway to mediate the degradation of Med13 following oxidative stress
}

\author{
Stephen D. Willis ${ }^{1}$, David C. Stieg ${ }^{1}$, Kai Li Ong ${ }^{2}$, Ravina Shah ${ }^{1,3}$, Alexandra K. Strich ${ }^{1,4}$, Julianne H. Grose ${ }^{2}$ and \\ Katrina F. Cooper ${ }^{1, *}$ \\ ${ }^{1}$ Department of Molecular Biology, Graduate School of Biomedical Sciences, Rowan University, Stratford, NJ, 08084, USA. \\ ${ }^{2}$ Department of Microbiology and Molecular Biology, Brigham Young University, Provo, UT 84602, USA. \\ ${ }^{3}$ Current address: Department of Biological Sciences, Rowan University, 201 Mullica Hill Rd, Glassboro, NJ 08028. USA. \\ ${ }^{4}$ Current address: Shawnee High School, Medford, New Jersey 08055, USA. \\ * Corresponding Author: \\ Katrina F. Cooper, Tel: (856)-566-2887, Fax: (856)-566-6366; E-mail: cooperka@rowan.edu
}

\begin{abstract}
Eukaryotic cells, when faced with unfavorable environmental conditions, mount either pro-survival or pro-death programs. The conserved cyclin C-Cdk8 kinase plays a key role in this decision. Both are members of the Cdk8 kinase module that, along with Med12 and Med13, associate with the core Mediator complex of RNA polymerase II. In Saccharomyces cerevisiae, oxidative stress triggers Med13 destruction, which releases cyclin $\mathrm{C}$ into the cytoplasm to promote mitochondrial fission and programmed cell death. The SCF $^{\text {Gr1 }}$ ubiquitin ligase mediates Med13 degradation dependent on the cell wall integrity pathway, MAPK SIt2. Here we show that the AMP kinase Snf1 activates a second $\mathrm{SCF}^{\mathrm{Grr}}$ responsive degron in Med13. Deletion of Snf1 resulted in nuclear retention of cyclin $C$ and failure to induce mitochondrial fragmentation. This degron was able to confer oxidative-stress-induced destruction when fused to a heterologous protein in a Snf1 dependent manner. Although snf1 $\Delta$ mutants failed to destroy Med13, deleting the degron did not prevent destruction. These results indicate that the control of Med13 degradation following $\mathrm{H}_{2} \mathrm{O}_{2}$ stress is complex, being controlled simultaneously by CWI and MAPK pathways.
\end{abstract}

doi: $10.15698 / \operatorname{mic} 2018.08 .641$ Received originally: 02.03.2018; in revised form: 29.05.2018, Accepted 04.06.2018, Published 25.06.2018.

Keywords: cyclin C, Cdk8, Med13, $S C F^{G r r}$, AMPK, Snf1, ubiquitin mediated destruction, signal transduction, $\mathrm{H} 2 \mathrm{O} 2$ stress, MAPK.
Abbreviations:
AMPK - 5' adenosine
monophosphate-activated protein kinase,
CKM - cyclin C/Cdk8 kinase module, $C W I-$ cell wall integrity, $I D R$ - intrinsic disordered region, MAPK - MAP kinase, $P C D$ - Programmed cell death, ROS - reactive oxygen species, $\mathrm{Y} 2 \mathrm{H}-$ yeast two hybrid.

\section{INTRODUCTION}

All eukaryotic cells are continually exposed to changing environmental conditions. Consequently, they have evolved elaborate mechanisms to both sense damage and transmit this signal to the nucleus. The resulting response varies dependent upon the stress encountered but in gross terms cells have to decide whether to activate pro-survival or pro-death programs. Despite this being a critical decision point, what remains understudied are the molecular details of how cells decide their fate upon encountering unfavorable environments. Previous studies revealed that the conserved cyclin $\mathrm{C}$ protein plays a key role in this decision in response to increased environmental reactive oxy- gen species (ROS) [1-9]. Cyclin C, together with its kinase partner Cdk8, Med12 and Med13, form the C $d k 8$ Kinase Module (CKM) of the multi-subunit Mediator complex. This complex acts as an interface between DNA bound transcription factors and RNA polymerase II (RNAP-II [10-12]). When the CKM module is bound, it predominantly negatively regulates expression of a subset of stress response genes [1, 13-16]. Following an increase in environmental ROS (induced by $\mathrm{H}_{2} \mathrm{O}_{2}$ treatment), this repression is relieved by the nuclear release of cyclin $\mathrm{C}$ to the cytoplasm [4, $7,8]$. Intriguingly, here cyclin C plays a second role directing stress-induced mitochondrial fission as well as promoting programmed cell death $(P C D)[7,8]$. Consistent with 
this function, cells lacking cyclin C are less able to execute stress-induced mitochondria fission and are more resistant to oxidative stress $[3,7]$. Taken together, these results argue that cyclin $C$ nuclear release must be carefully controlled as it signals a commitment to PCD.

Our previous studies have revealed that a complex molecular mechanism controls cyclin $\mathrm{C}$ nuclear release. In response to environmental ROS, cyclin $C$ is directly phosphorylated by Slt2, the MAP kinase of the Cell Wall Integrity (CWI) signal transduction pathway ([6] and Fig. 1A). This canonical pathway is characterized by a family of cellsurface sensors (Wsc1, Mid2 and Mtl1 [17]) that transmit the stress to a small $\mathrm{G}$ protein Rho1, which thereafter activates protein kinase C (Pkc1 $[18,19])$. Once activated, Pkc1 transmits the intracellular signal to the MAPK Slt2/Mpk1 [20] as well as to the pseudo-kinase $\mathrm{Kdx} 1 / \mathrm{Mlp} 1$ via the MAPK module [21]. In addition to cyclin C [6], SIt2 directly phosphorylates two other transcription factors (RIm1, Swi4/Swi6) that stimulate the expression of other stress response genes [21-24]. More recently, SIt2 has also been shown to regulate gene expression by phosphorylating tyrosine-1 of the RNAP II carboxy-terminal domain [25]. This event is associated with pause/termination processes in mammals [26]. Intriguingly, it is required for the loss of cyclin C and Cdk8 from target genes following stress in yeast [25].
In S. cerevisiae, Med13 destruction is required for cyclin C nuclear release [27]. Consistent with this, cyclin C is cytoplasmic in unstressed med13 $\Delta$ and the mitochondria are predominantly fragmented [27]. More recently we identified $\mathrm{SCF}^{\mathrm{Grr} 1}$ as the $\mathrm{E} 3$ ligase that mediates Med13 destruction [9]. Like other SCF targets [28], recognition of this phospho-degron requires it first to be primed by one kinase (cyclin C-Cdk8) and then activated by another (SIt2). These studies also revealed that phosphorylation of cyclin $\mathrm{C}$ by Slt2 is required for the SCF ${ }^{\mathrm{Grr} 1}$ to recognize Med13 ([9] and Fig. 1A). Like the Slt2-degron, this domain lies within the large intrinsic disordered region (IDR) of Med13 (Fig. 2A). IDR's are defined by a continuous stretch of disordered promoting residues which can easily transition into more ordered states. These structural transitions afford IDR's great flexibility and as such these regions are known to play key roles in macro-molecular decisions especially those that influence signaling pathways [29, 30].

In addition to Slt2, the highly conserved $5^{\prime}$ adenosine monophosphate-activated protein kinase (AMPK), which plays a major role in the utilization of alternative carbon sources after glucose depletion [32], is also activated in response to various environmental stresses including oxidative stress [33]. In S. cerevisiae, the catalytic subunit of the heterotrimeric AMPK complex is encoded by SNF1. Other members of the complex (outlined in Fig. 1B) include two regulatory subunits, the $\gamma$ subunit Snf4 and one of the
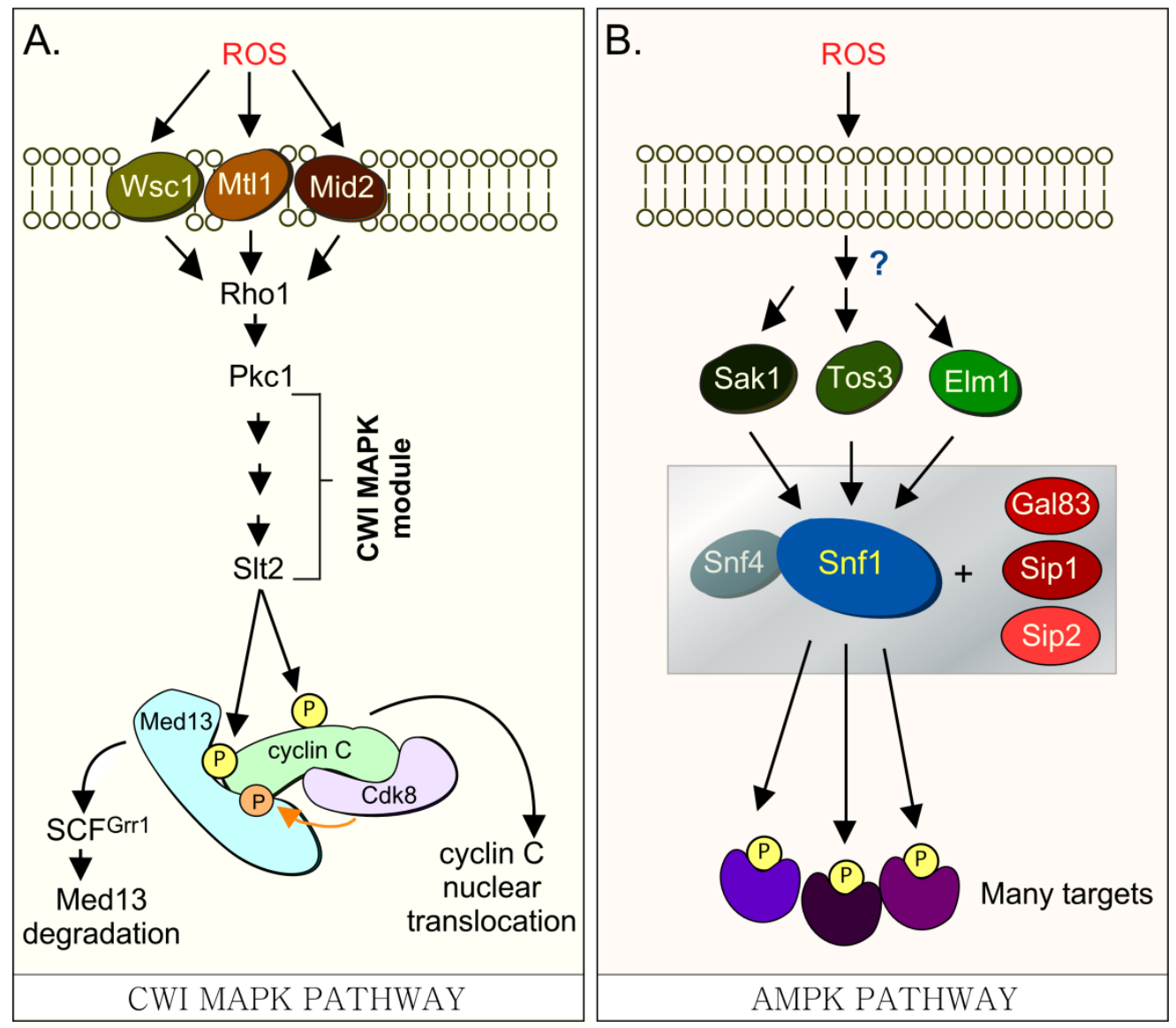

FIGURE 1: (A) Cdk8 module regulation by the $\mathrm{CWI}$ MAPK pathway. $\mathrm{H}_{2} \mathrm{O}_{2}$ stimulates cell wall sensors Wsc1, Mtl1 and Mid2, leading to activation of Rho1 that in turn triggers the cell wall integrity (CWI) MAPK pathway by activating Protein Kinase C (Pkc1). Activation of this cascade triggers the MAPK, SIt2, to directly phosphorylate cyclin $C$, an event required for the $1^{\text {st }}$ step towards its release from the nucleus. The second step requires Slt2 to directly phosphorylate Med13-degron ${ }^{742-844}$, which targets it for ubiquitin mediated degradation by $\mathrm{SCF}^{\mathrm{Gr} 1}$. Cyclin C-Cdk8 activity is needed to prime the degron before it is recognized by $\mathrm{SCF}^{\mathrm{Gr} 1}$ [9]. (B) Outline of the AMPK pathway in yeast. It remains unknown how this pathway is activated in response to $\mathrm{H}_{2} \mathrm{O}_{2}$ stress. The gray box represents the Snf1 kinase complex (see text for details). 
three alternative $\beta$ subunits, Sip1, Sip2, or Gal83 [32]. The three $\beta$ isoforms determine the respective cellular addresses after activation of Snf1, with the Snf1-Gal83 isoform being enriched in the nucleus [34-36]. The catalytic activity of Snf1 is regulated by phosphorylation at Thr-210, which is located in the activation loop of its kinase domain [37]. This is executed by one of three upstream kinases, Sak1, Tos3, or Elm1 [33, 38, 39]. These, in turn, are activated by an unknown mechanism in response to a variety of stresses, which lends specificity to the system [33].

In this report we show that Snf1, Sak1 and at least one $\beta$ isoform are required for the $\mathrm{H}_{2} \mathrm{O}_{2}$ induced degradation of Med13. Using yeast two-hybrid analysis, the Snf1interacting domain on Med13 was identified. This domain lies in the large IDR of Med13 and is recognized by SCF ${ }^{\text {Grr1 }}$ after Snf1 directed phosphorylation. Consistent with this, Snf1 is required for efficient cyclin $\mathrm{C}$ nuclear release following $\mathrm{H}_{2} \mathrm{O}_{2}$ stress. Taken together, this reveals that Med13 degradation is regulated by two $\mathrm{SCF}^{\mathrm{Grr} 1}$ degrons that are regulated by three different classes of kinases, a Cdk, a MAPK and an AMPK. As all three kinases are required for Med13 degradation, this complex molecular mechanism ensures that cyclin $C$ nuclear release is tightly controlled and prevents its untimely release into the cytoplasm.

\section{RESULTS}

\section{Med13 contains two SCF ${ }^{\text {Grr1 }}$ phospho-degrons}

We have previously shown that $\mathrm{SCF}^{\mathrm{Grr}}$ is the $\mathrm{E} 3$ ligase responsible for mediating Med13 degradation following $\mathrm{H}_{2} \mathrm{O}_{2}$ stress [9]. This degron (amino acids 742-844, Fig. 2A,) is primed by cyclin C-Cdk8 and activated by SIt2. In these studies we also observed that another Med13 domain (amino acids 571-650) can also bind to Grr1 using the Gal4 yeast two hybrid $(\mathrm{Y} 2 \mathrm{H})$ assay [40]. These results were repeated using two baits, wild-type Grr1 and a grr1 $\Delta F \Delta L$ mutant, which can neither bind to the SCF or recognize substrates [41, 42]. As anticipated, the Gal4 activating domain Med13 $3^{571-650}$ fusion protein (hereon out referred to as degron ${ }^{571-650}$ ) can associate with wild-type Grr1 as an interaction is detected selecting for the dual HIS3 and ADE2 reporter genes (Fig. 2B). The vector control and mutant bait were unable to grow on this media suggesting that the interaction is specific.

To confirm that degron ${ }^{571-650}$ is responsive to $\mathrm{SCF}^{\mathrm{Grr} 1}$ we examined its degradation, via Western blot analysis, following $0.4 \mathrm{mM} \mathrm{H}_{2} \mathrm{O}_{2}$ treatment in wild-type and grr1 $\Delta$ cells. This concentration of $\mathrm{H}_{2} \mathrm{O}_{2}$ induces mitochondrial outer membrane permeabilization (MOMP) dependent regulated cell death response in yeast [43-45] and triggers cyclin $C$ nuclear release $[4,6,7,27]$. The results show that although less degron ${ }^{571-650}$ is present in unstressed grr1 $\Delta$ cells, the protein is more stable following $\mathrm{H}_{2} \mathrm{O}_{2}$ stress (Fig. $2 \mathrm{C}$ and quantified in 2D). Taken together with the $\mathrm{Y} 2 \mathrm{H}$ data, these results argue that degron ${ }^{571-650}$ is a $\mathrm{SCF}^{\mathrm{Gr} 1}$ responsive degron. They are also consistent with our previous published work demonstrating that Grr1 is required for $\mathrm{H}_{2} \mathrm{O}_{2}$ induced degradation of Med13 [9].
A.

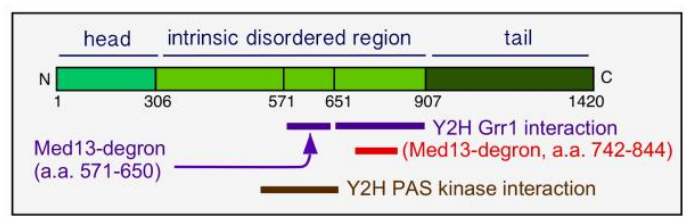

B.

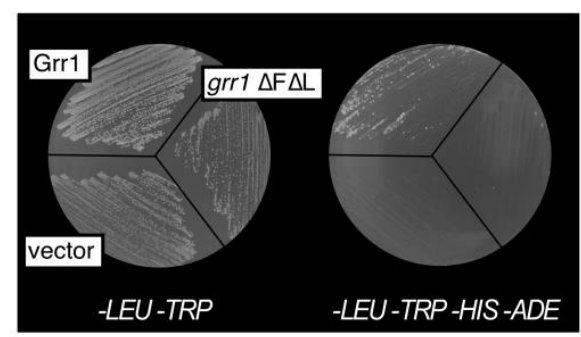

C.

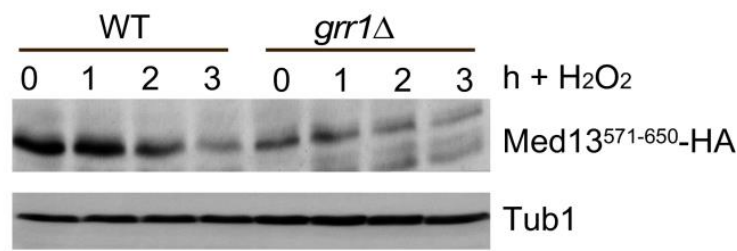

D.

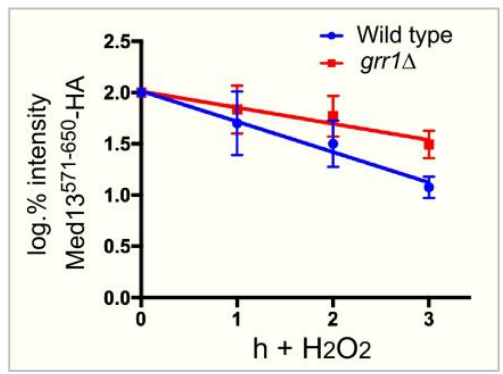

FIGURE 2: Med13 contains two $\mathrm{H}_{2} \mathrm{O}_{2}$ stress responsive degrons. (A) Cartoon of the results from ProteinPredict ${ }^{\circledR}$ [89] analysis of yeast Med13. The amino and carboxyl terminal domains are structured and separated by a large intrinsic disordered region. The positions of the two degrons are indicated. (B) Yeast two hybrid analysis of degron ${ }^{571-650}$ and Grr1 derivatives. Yeast PJ69-4a cells harboring Med13-activating domain plasmid (pDS15) and either pAS2, pAS-Grr1 or pAS2-Grr1 $\Delta \mathrm{F} \Delta \mathrm{L}$ binding domain plasmids were grown on -LEU, -TRP drop out medium to select for both plasmids (left panel) and -TRP, -LEU, -HIS -ADE (right panel) to test for Med13-Grr1 interaction. (C) Wild-type (RSY10) or grr1 $\Delta$ cells (RSY1770) harboring degron ${ }^{571-650}$ (pDS15) were treated with 0.4 $\mathrm{mM} \mathrm{H} \mathrm{O}_{2}$ for the timepoints indicated and Med13 ${ }^{571-650}$-HA levels analyzed by Western blot. Tub1 levels were used as loading controls. (D) Degradation kinetics of the degron ${ }^{571-650}$ constructs shown in C. Values represent averages \pm SD from a total of at least two Western blots from two independent experiments.

Snf1 is required for stress-induced degradation of Med13 We next addressed if the $\mathrm{H}_{2} \mathrm{O}_{2}$ mediated destruction of degron ${ }^{571-650}$ required Cdk8 kinase activity. To execute this, the degradation of degron ${ }^{571-650}$ was monitored as de- 
scribed above, in cells deleted for cyclin $\mathrm{C}$ harboring either functional myc-tagged cyclin $\mathrm{C}$ or a vector control. The results revealed that degron ${ }^{571-650}$ is degraded with the same kinetics in the presence or absence of cyclin C (Fig. S1A and quantified in Fig. S1B). These results suggest that another kinase phosphorylates degron ${ }^{571-650}$. One candidate is the PAS kinase. This kinase is required for glucose homeostasis, and is encoded by two orthologs Psk1 and Psk2 [46]. Intriguingly, previous $\mathrm{Y} 2 \mathrm{H}$ studies have revealed that a domain of Med13 (amino acids 505-703), that encompasses degron ${ }^{571-650}$, interacts with Psk1 [47]. The $\mathrm{Y} 2 \mathrm{H}$ assay was repeated using Psk1 as bait and the smaller degron ${ }^{571-650}$ as prey and again an interaction was observed (Fig. S2A). We next tested if the PAS kinase plays a role in the degradation of full length Med13. Wild-type and psk1 psk2 $\Delta$ cells harboring a functional HA-tagged Med13 plasmid [9] were treated with $\mathrm{H}_{2} \mathrm{O}_{2}$ and Med13 degradation was monitored by Western blot analysis. The results show that Med13 is degraded with similar kinetics in the mutant and wild-type cells (Fig. S2B and quantified in Fig. S2C).
These results indicate that although the PAS kinase can interact with degron ${ }^{571-650}$, it is not required for Med13 degradation following $\mathrm{H}_{2} \mathrm{O}_{2}$ stress.

PAS kinase activation by carbon sources is dependent on the Snf1 complex $[48,49]$. Since Snf1 has many targets [50], we next tested if Snf1 mediates Med13 degradation following $\mathrm{H}_{2} \mathrm{O}_{2}$ stress as just described. The results show that Med13 is significantly more stable in snf1 $1 \Delta$ cells (Fig. $3 \mathrm{~A}$ and quantified in Fig. $3 \mathrm{C}$ ). Similar results were obtained when the Snf1 kinase dead mutant (K84R, [51]) was the only source of Snf1 (Fig. 3B and quantified in Fig. 3D). Taken together, these results indicate that Snf1 activity is required for Med13 degradation following $\mathrm{H}_{2} \mathrm{O}_{2}$ stress.

Sak1 has been identified as the AMPK kinase that is activated in response to oxidative stress [33]. Therefore, we next addressed if Sak1 is required for $\mathrm{H}_{2} \mathrm{O}_{2}$ induced Med13 degradation. The degradation assays described above were repeated in sak1 $\Delta$ cells and results revealed that Med13 was again significantly more stable in $s a k 1 \Delta$ than wild-type cells (Fig. 3A and quantified in Fig. 3C). This result supports

A.

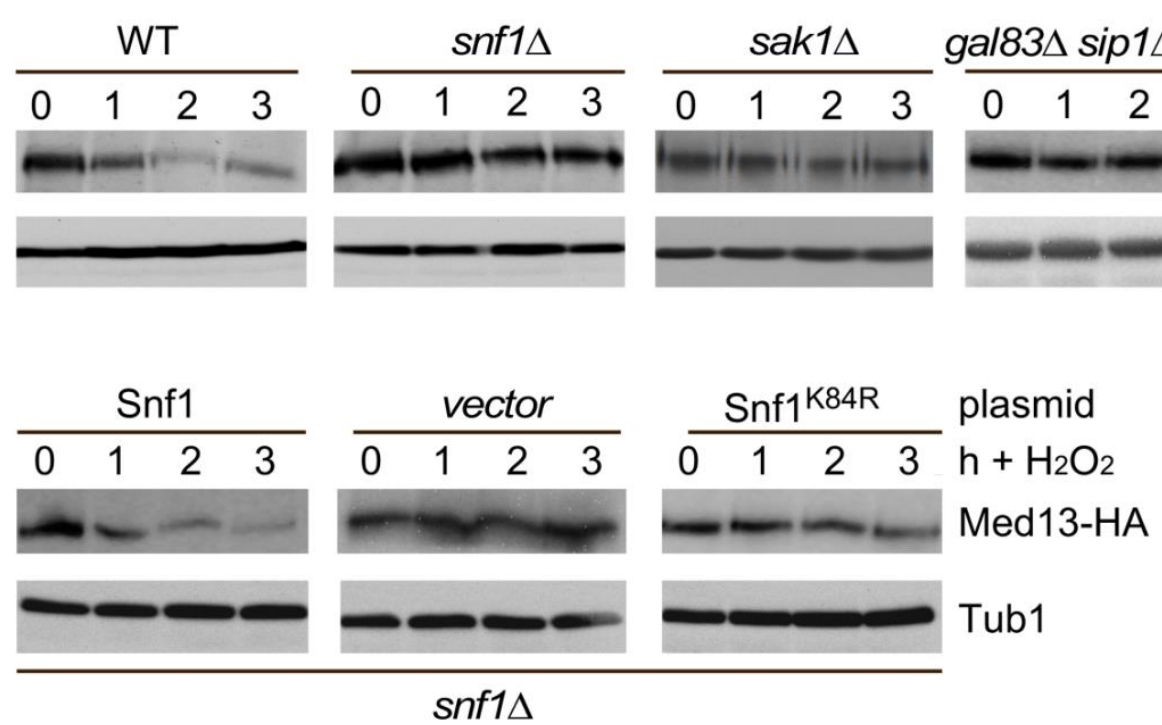

C.

D.
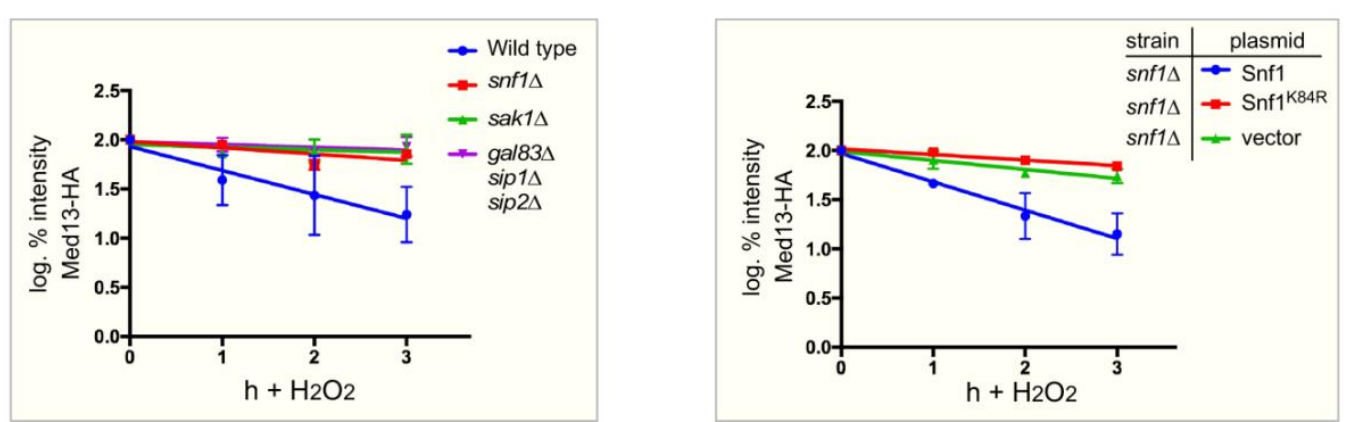

FIGURE 3: Snf1, Sak1 and at least one $\boldsymbol{\beta}$ subunit are required for degradation of Med13 following $\mathrm{H}_{2} \mathrm{O}_{2}$ stress. (A) Wild-type (RSY10),

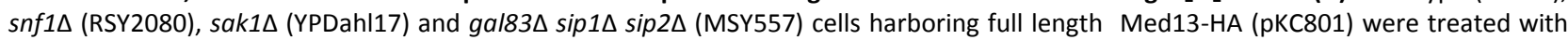
$0.4 \mathrm{mM} \mathrm{H}_{2} \mathrm{O}_{2}$ for the timepoints indicated and Med13-HA levels analyzed by Western blot. Tub1 levels were used as a loading control. (B) snf1 1 cells harboring Med13-HA (pKC803) and either wild- type Snf1 (JG1193), a vector control (pRS316) or snf1 ${ }^{\mathrm{K} 84 \mathrm{R}}$ (JG1338) were treated and analyzed as described in A. (C and D) Degradation kinetics of the Med13-HA shown in A and B. Values represent averages \pm SD from a total of at least two Western blots from independent experiments. 
the previously proposed model that Sak1 is the AMPKK that activates Snf1 in response to oxidative stress [33]. We next addressed if the nuclear enriched isoform, Snf1-Gal83, [34-36, 52], is required for Med13 degradation under similar circumstances. Unexpectedly, the results show that Med13 is still degraded in gal83 $\Delta$ cells (Fig. S3A). Likewise, similar results were obtained when Med13 degradation was monitored in a $\operatorname{sip} 1 \Delta \operatorname{sip} 2 \Delta$ strain (Fig. S3A). However, deletion of all three $\beta$ subunits significantly inhibited the degradation of Med13 to a similar extend as observed in snf1 $\triangle$ (Fig. $3 \mathrm{~A}$ and quantified in Fig. $3 \mathrm{C}$ ). Taken together, this suggests at least one of the $\beta$ subunits of the Snf1 complex is required for Med13 degradation following $\mathrm{H}_{2} \mathrm{O}_{2}$ stress.

\section{Snf1 activation alone is not sufficient to mediate Med13 degradation}

We next addressed if Snf1 activation was sufficient to mediate Med13 degradation in the absence of $\mathrm{H}_{2} \mathrm{O}_{2}$ stress. To execute this Med13 levels were examined in wild-type cells after they had been switched from $2 \%$ to $0.05 \%$ glucose which, is sufficient to activate Snf1 (Fig. 4A and [33]). No differences in Med13 levels were observed following glucose deprivation (Fig. 4B). Taken with the results presented in Fig. 3, this suggests that Snf1 activation is necessary but not sufficient to mediate the degradation of Med13 following $\mathrm{H}_{2} \mathrm{O}_{2}$ treatment.

\section{The CWI pathway sensors proteins are not required for Snf1 activation}

It is known that both the CWI and AMPK pathways are activated in response to oxidative stress, but how these two pathways communicate is not well understood [53]. Importantly, although it is known how the signal is transmitted to the CWI pathway, it is unclear how the AMPK pathway is activated (Fig. 1B). One possibility is that the pathways crosstalk through the cell wall sensor proteins. To test this, we examined Snf1 phosphorylation status in a strain lacking the three cell wall sensors (Wsc1, Mid2 and Mtl1, [17]). Consistent with previously published work [33], Snf1 is phosphorylated following $\mathrm{H}_{2} \mathrm{O}_{2}$ treatment in a Sak1 dependent manner (Fig. 4C). Likewise the cell wall sensor triple mutant is also able to activate Snf1 following $\mathrm{H}_{2} \mathrm{O}_{2}$ treatment (Fig. 4C). These results suggest that the activation of the CWI pathway is not required to transmit the stress signal to the AMPK pathway. Others have demonstrated that Snf1 is not required for activation of Slt2 [54]. Consistent with this, we observed that the Med13 degron ${ }^{571-650}$ is still degraded following $\mathrm{H}_{2} \mathrm{O}_{2}$ stress when a mutant of cyclin $\mathrm{C}$, that cannot be phosphorylated by Slt2 (S266A, [6]), is used as the sole source of cyclin C (Fig. S1C and D). Taken together, these results argue that the AMPK and MAPK signaling pathways act independently of each other. The extension of this conclusion is that both pathways contribute independently to regulating Med13 destruction following $\mathrm{H}_{2} \mathrm{O}_{2}$ stress.
A.

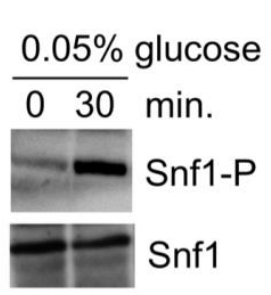

B.

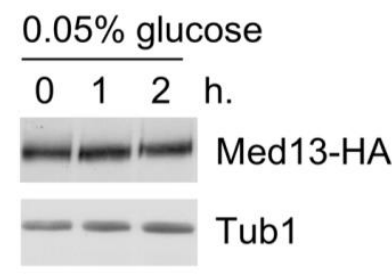

C.

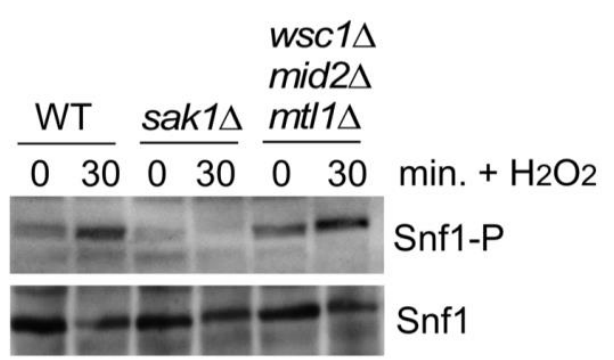

FIGURE 4: Snf1 activation does not mediate Med13 degradation. (A) Mid-log -type cells (RSY10) growing in $2 \%$ glucose $(T=0)$ were switched to media containing $0.05 \%$ glucose. Snf1 phosphorylation and Snf1 itself were detected as described in materials and methods for the timepoint indicate. (B) Wild-type cells harboring Med13-HA (pKC801) were switched to media containing 0.05\% glucose. Med13-HA levels were detected by Western blot analysis for the timepoints indicated. Tub1 was used as a loading control. (C) As in (A) except that Snf1 phosphorylation was monitored after $0.4 \mathrm{mM} \mathrm{H}_{2} \mathrm{O}_{2}$ treatment in the strains indicated.

\section{The Snf1 degron lies within the IDR of Med13}

Snf1 has previously been shown to phosphorylate a SCF ${ }^{\mathrm{Gr} 1}$ phospho-degron in Pfk27, a key regulator of glycolysis [55]. Taking this into account, we asked if the Gal4 activating domain Med1 $13^{571-650}$ fusion protein (degron ${ }^{571-650}$ ) is a Snf1 responsive degron by monitoring its $\mathrm{H}_{2} \mathrm{O}_{2}$ mediated degradation snf1 $1 \Delta$ cells. The results show that degron ${ }^{571-650}$ is more stable in snf1 $\Delta$ cells compared to wild type following $\mathrm{H}_{2} \mathrm{O}_{2}$ stress (Fig. $5 \mathrm{~A}$ and quantified in Fig. 5B). This suggests that degron ${ }^{571-650}$ is a Snf1 responsive degron. To further support this conclusion, we examined the degradation kinetics of a degron mutated for either of the potential Snf1 phosphorylation sites previously identified in proteomic screens (S587 [56] and S636 [57], Fig.6A), although none of these sites perfectly fit the Snf1 consensus sequence $[58,59]$. The studies revealed that both mutants were degraded following $\mathrm{H}_{2} \mathrm{O}_{2}$ treatment with kinetics similar to wild type (Fig. S3B). We also noted that serine 634 could potentially be phosphorylated by Snf1 (see Fig. $6 A)$. As it lies very close to serine 636 , we made a double mutant (S634A, S636A) and repeated the assay. Again this mutant degron was degraded following $\mathrm{H}_{2} \mathrm{O}_{2}$ treatment (Fig. S3B). However, the triple mutant (S587A, S634A, S636A) exhibited enhanced stability following $\mathrm{H}_{2} \mathrm{O}_{2}$ stress (Fig. $5 \mathrm{C}$ and quantitated in Fig. 5B). Taken together, these results suggest that Snf1 phosphorylates Med13 following $\mathrm{H}_{2} \mathrm{O}_{2}$ stress targeting S587, S634 and S636. Consistent with this 
A.

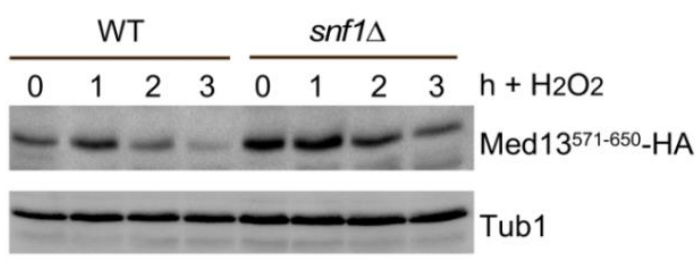

C. S587A, S634A, S636A

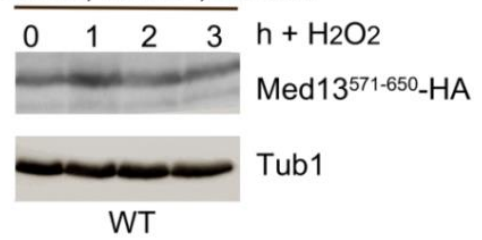

D.

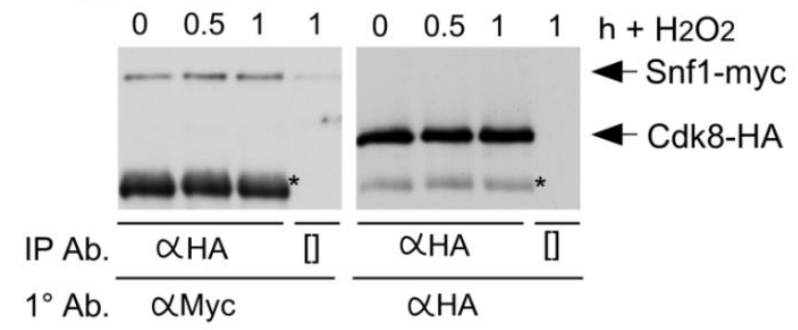

E.

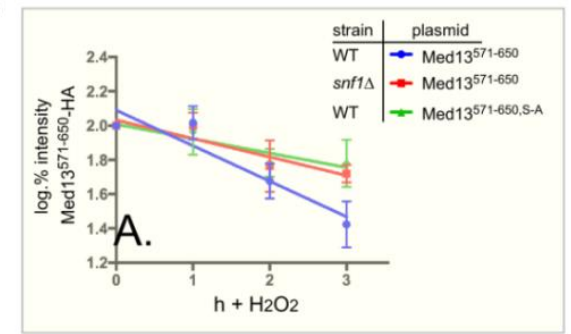

571 KRKYLDIPID EMTLPTSPLY Green Potential Snf1 sites

591 MDPGAPLPVE TPRDRRKSVF Blue PKA site

611 APLNFNPIIE NNVDNKYKSG Red Potential Cdk and MAPK consensus site

631 GKFSFSPLOK EEALNFDISM Purple/Shared potential site between Snf1 and Cdk/MAPK

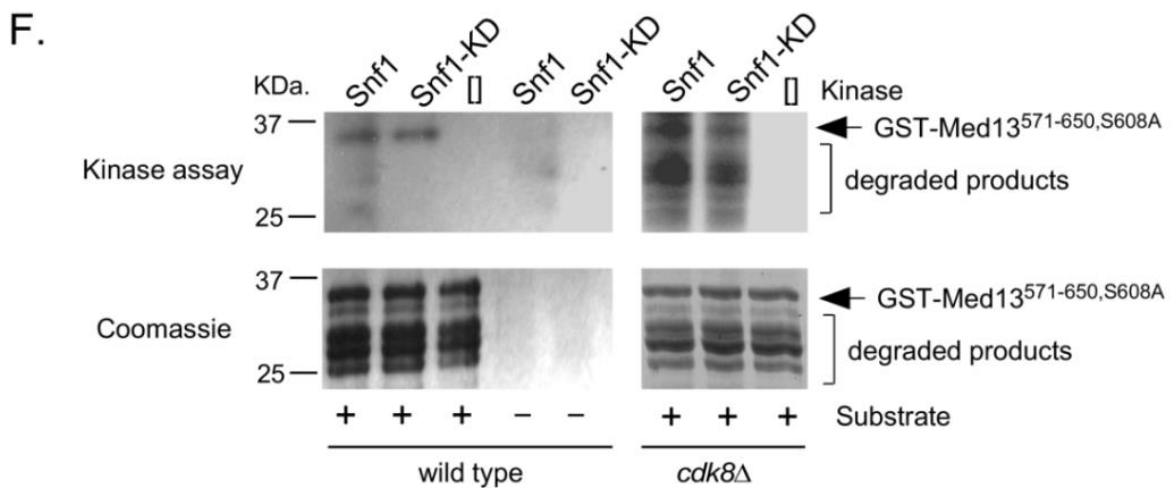

FIGURE 5: Snf1 phosphorylates degron ${ }^{571-650}$. (A) Mid-log wild-type (RSY10) or snf1 cultures (RSY202) harboring degron $^{571-650}$ (pDS15) were subjected to an $\mathrm{H}_{2} \mathrm{O}_{2}$ timecourse experiment and protein extracts analyzed by Western blot. Tub1 levels were used as loading controls. (B) Degradation kinetics of degron ${ }^{571-650}$ shown in A and C. Values represent averages \pm SD from a total of at three Western blots from independent experiments. (C) As in A except that degron ${ }^{571-650,5587 A, ~ 5634 A, ~ 5636 A ~}$ (pDS56) was analyzed in wild-type cells. (D) Co-immunoprecipitation analysis of Snf1-myc and Cdk8-HA. Mid log wild-type cells harboring Snf1-myc and Cdk8-HA on single copy plasmids were treated with 0.4 $\mathrm{mM} \mathrm{H}_{2} \mathrm{O}_{2}$ for the timepoints shown. Protein extracts were immunoprecipitated with anti-HA, separated by SDS-PAGE Western analysis and the membrane probed with the antibodies shown. [] represents no IP antibody and the asterisk represents the heavy chain. See Fig. S3C for vector control. (E) Potential phospho-sites in Med13 ${ }^{571-650}$. (F) Upper panels: Kinase assays using Snf1 and Snf1 ${ }^{\mathrm{K} 4 \mathrm{R}}$-myc (kinase dead) immunoprecipitated from yeast protein extracts prepared from either wild type (left panel) or cdk8 cells (right panel) and Med13-degron ${ }^{571-650}$ (GST-Med13 ${ }^{571-906,5608 A}$ purified from E. coli) as the substrate. The reactions were separated by SDS PAGE and subject to autoradiography. Lower panels: Coomassie stained gels showing the input used in the kinase assays.

model, we (Fig. 5D and S3C) and others [60] have shown that Snf1 can co-immunoprecipitate with Cdk8 both before and after $\mathrm{H}_{2} \mathrm{O}_{2}$ stress. As cyclin $\mathrm{C}$ directly binds to the adjacent degron ${ }^{742-844}$ (Fig. 2A and [9]), this places Snf1 in close proximity to degron ${ }^{571-650}$. In addition, these data also support the notion suggested by others, that a subpopulation of Snf1 is nuclear in unstressed cells $[34,52,60]$.

To address if Snf1 directly phosphorylates Med13, kinase assays were performed with wild-type and kinase dead Snf1 (K84R). The activated kinase was immunoprecipitated from yeast extracts and incubated with GSTMed13 ${ }^{561-650,5608 A}$ purified from E. coli. Serine 608 was mutated to alanine as it potentially is contaminating PAS kinase site (Fig. 5E and [49]). In addition, although this site has also been identified as target of PKA mediated phosphorylation [61], we have previously shown that this site does not play a role in Med13 degradation in response to oxidative stress [9]. Lastly, it is documented that Snf1 does 
not phosphorylate GST, so this control was not included here [62]. The results (Fig. 5F) show that Snf1 is able to directly phosphorylate degron ${ }^{571-650}$. However, despite taking the precautions listed above, kinase activity was also observed using the kinase dead version. This suggests that another kinase that immunoprecipitates with Snf1 is able to phosphorylate this degron. One strong possibility is Cdk8, which is a proline directed kinase that can phosphorylate the minimal consensus sequence S/T-P [63]. Degron ${ }^{571-650}$ contains one such site (Fig. 5E). Therefore the kinase assays were repeated using Snf1 extracts isolated from a $c d k 8 \Delta$ strain. The results show that degron ${ }^{571-650}$ was phosphorylated by Snf1 and this activity was reduced in the kinase dead control (Fig. 5F). Taken together, these results are suggestive that Snf1 directly phosphorylates Med13 ${ }^{571-650}$. However, as some phosphorylation of degron ${ }^{571-650}$ was observed when Snf1 ${ }^{\mathrm{K} 4 \mathrm{R}}$ was used, we cannot rule out the possibility that an intermediary kinase may be playing a role.

Other potential Snf1 sites on Med13 are not needed for its degradation following $\mathrm{H}_{2} \mathrm{O}_{2}$ stress

The Snf1 proteomic screen mentioned above also identified five additional potential Snf1 sites in Med13 [57]. Intriguingly, these sites all lie within the large IDR of Med13 (Fig. 6A). As IDR's provide ideal environments for posttranslational modifications, which effect signaling events [64], we asked if these additional sites also play a role in Med13 degradation. To address this question, Med13-HA fragments were fused to the SV40 nuclear localization sequence (NLS) and assayed for $\mathrm{H}_{2} \mathrm{O}_{2}$ mediated destruction. The results revealed that the construct that contains both degrons as well as all the potential Snf1 sites (amino acids 306-906) is degraded. However, the Med13 $3^{306-570}$ construct, that contains the remaining potential Snf1 sites but not the two $\mathrm{SCF}^{\mathrm{Grr} 1}$ responsive degrons, was significantly more stable (Fig. 6B). This suggests that these other potential Snf1 sites do not play a role in the $\mathrm{H}_{2} \mathrm{O}_{2}$-stress mediated degradation of Med13. To address if the head and tail regions of Med13 contain unidentified Snf1 sites, Med13 constructs spanning these regions (amino acids 1-306 and 907-1420) were also tested, as described above, for stability following $\mathrm{H}_{2} \mathrm{O}_{2}$ stress. The results (Fig. $6 \mathrm{C}$ ) demonstrate that these constructs are not destroyed under these conditions. This supports our conclusion that the Snf1 degron lies within amino acids $571-650$. Degron ${ }^{742-844}$ also contains a potential Snf1 target site (Fig. 6A). However, this degron, when fused to the Gal4 activating domain, is destroyed following $\mathrm{H}_{2} \mathrm{O}_{2}$ stress in wild-type and snf1 $1 \Delta$ cells alike (Fig. 6D). Taken together, these results support the above conclusions that the Snf1 phosphorylation sites lie within degron ${ }^{571-650}$.

\section{Snf1 is necessary for cyclin C nuclear release and stress-} induced mitochondrial fission

As Med13 degradation is required for cyclin $C$ nuclear release $[9,27]$, we next tested if Snf1 was also required for this event. To address this, the location of a functionalcyclin C-YFP reporter protein [5] before and after stress in wild-type and snf1 $\Delta$ cells was examined (Fig. 7A and quan-
A.

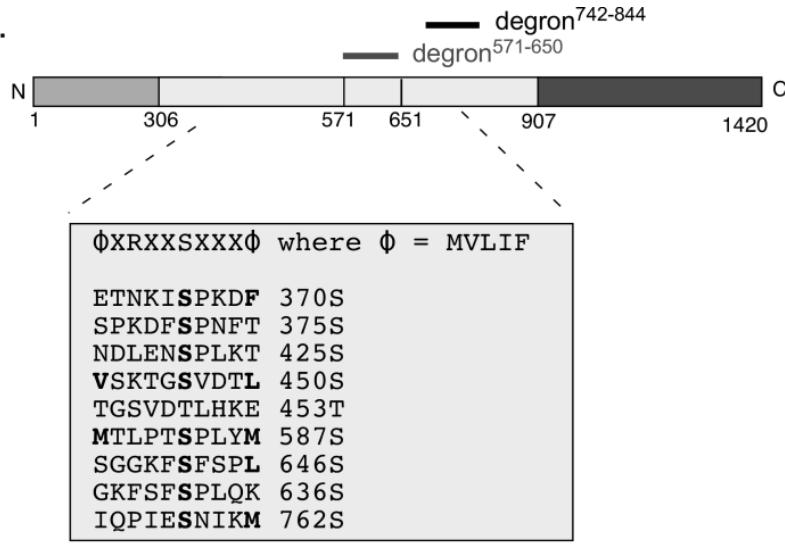

B.
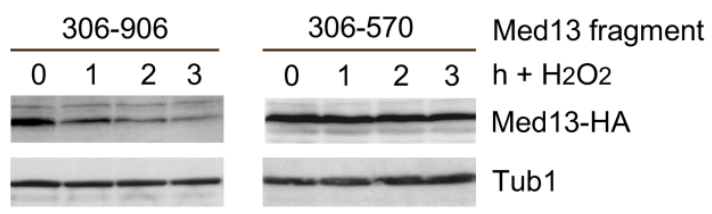

C.

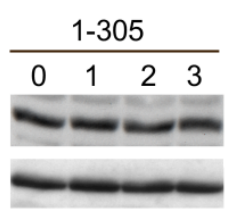

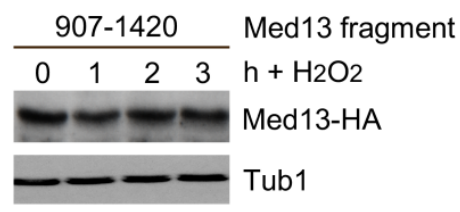

D.

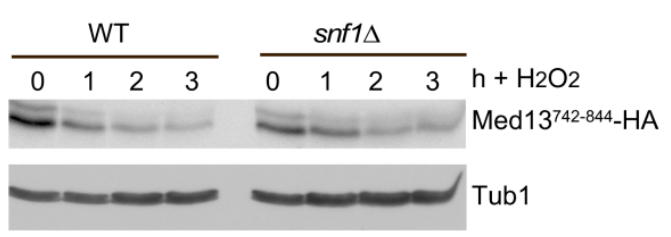

FIGURE 6: Other potential Snf1 sites in Med13 are not required for its degradation following $\mathrm{H}_{2} \mathrm{O}_{2}$ stress. (A) Map of Med13 outlying the positions of the two Med13 degrons, the consensus Snf1 target site [57] and potential Snf1 sites, identified by published proteomic screens. (B) and (C) Wild-type (RSY10) cultures harboring the NLS-Med13-HA constructs shown were grown to mid-log phase $(0 \mathrm{~h})$ then treated with $0.4 \mathrm{mM} \mathrm{H}_{2} \mathrm{O}_{2}$ for the indicated times. Med13-HA levels were determined by Western blot analysis. Tub1 levels were used as a loading control. (D) Mid-log wild type or snf1 $1 \Delta$ cultures (RSY202) harboring HA tagged Med13 degron742-844 (pDS32) were subjected to an $\mathrm{H}_{2} \mathrm{O}_{2}$ timecourse experiment and protein extracts analyzed by Western blot. Tub1 levels were used as loading controls.

tified in 7B). The results show that a majority of cyclin CYFP is cytoplasmic in wild-type cells, whereas it remains significantly more nuclear in snf1 $\Delta$ cells (Fig. 7A and quantified in 7B). These data indicate that Snf1 is required for the oxidative stress induced nuclear release of cyclin C. As cyclin $C$ nuclear release initiates stress-induced mitochondrial fission $[4,7,8]$, mitochondrial morphology in snf1 $\Delta$ cells was examined. As previously reported, unstressed wildtype cells exhibited mainly reticular mitochondrial mor- 
A.

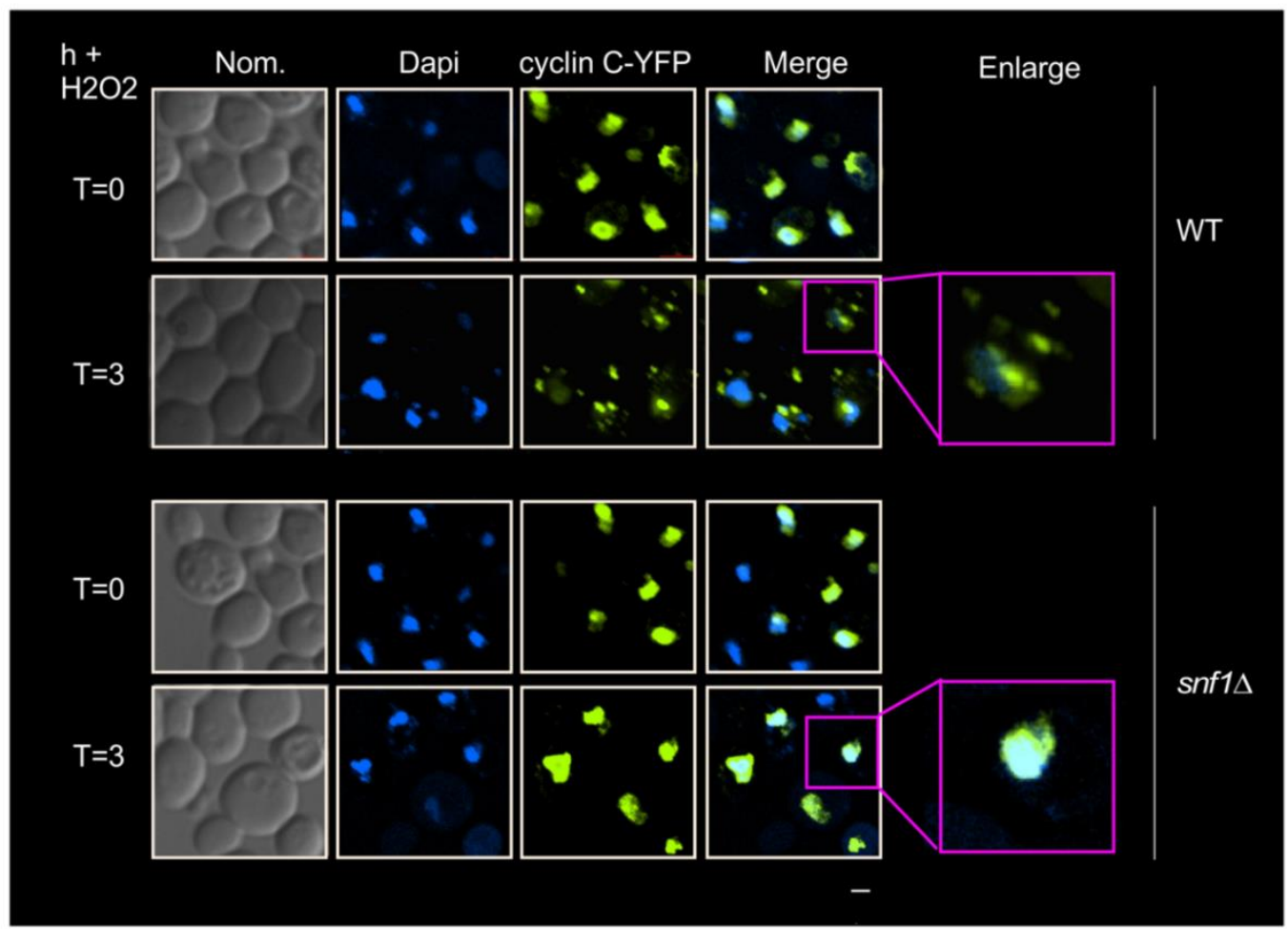

B.

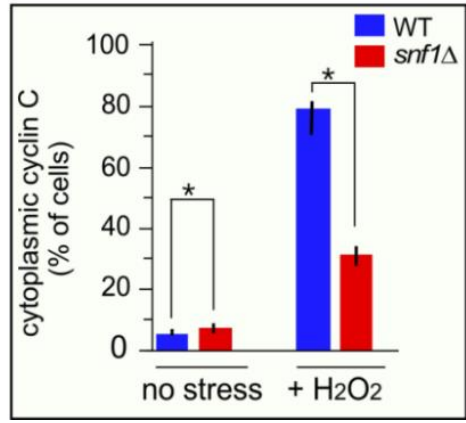

C.

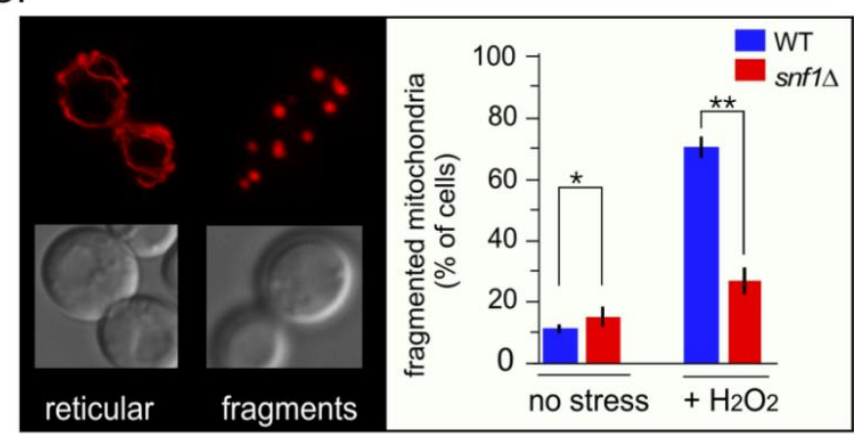

FIGURE 7: Cyclin C remains predominantly nuclear following $\mathrm{H}_{2} \mathrm{O}_{2}$ stress in snf1வ. (A) Fluorescence microscopy of mid-log phase wild-type and snf1 $\triangle$ cells harboring a cyclin C-YFP expression plasmid (pBK38). Cells were stained with Dapi to visualize the nucleus. (B) Quantification of the results obtained in (A). At least 200 cells were counted per timepoint from 3 individual isolates. The percent of cells (mean \pm SEM) within the population displaying cytoplasmic cyclin $C$ is given. ${ }^{*} p<0.05$ difference from wild type. (C) Right panel: representative images of the two mitochondrial morphologies scored. Left panel: as in (B) except that percent of cells displaying fragmented mitochondria was scored. Representative images of the mitochondrial morphologies scored are shown in the left hand panel. The percent of cells (mean \pm s.e.m.) within the population displaying fragmented mitochondria is given. ${ }^{*} p<0.05$ difference from wild type. ${ }^{* *} p<0.01$ difference from wild type. Bar $=13 \mu \mathrm{M}$.

phology (Fig. 7C) that switched to a predominantly fragmented phenotype after 3 hours of $0.4 \mathrm{mM} \mathrm{H}_{2} \mathrm{O}_{2}$ treatment. In snf1 $1 \Delta$ cells, significantly less fragmented mitochondria are seen after $\mathrm{H}_{2} \mathrm{O}_{2}$ treatment. Taken together, these results indicate that activation of Snf1 is required for stress-induced mitochondrial fragmentation through cyclin C nuclear release.

\section{Med13-degron ${ }^{571-650}$ is not required for the degradation of Med13 following $\mathrm{H}_{2} \mathrm{O}_{2}$ stress}

We next addressed if Snf1 mediated phosphorylation of Med13 is required for Med13 degradation. Degron ${ }^{571-650}$ was deleted from full length Med13 and the degradation kinetics of this construct (Med1 $3^{\operatorname{deg} \Delta 571-650}$ ) was examined in med13 $\Delta$ cells. The results show that Med13 $3^{\operatorname{deg} \Delta 571-650}$ was degraded with kinetics similar to wild type (Fig. 8A upper two panels, quantified in Fig. 8B). We also observed that this construct retained cyclin $\mathrm{C}$ in the nucleus in unstressed cells and released it into the cytoplasm following $\mathrm{H}_{2} \mathrm{O}_{2}$ stress (Fig. S5). These results were unexpected as deletion or inactivation of Snf1 results in Med13 stabilization following $\mathrm{H}_{2} \mathrm{O}_{2}$ stress (Fig. 3). Similarly, deletion of the Slt2 responsive degron (amino acids 742-844) only partially rescued the deletion (Fig. $8 \mathrm{~A}$, bottom two panels) whereas Med13 is significantly stabilized in s/t2 $\Delta$ cells following $\mathrm{H}_{2} \mathrm{O}_{2}$ stress [9]. These results suggest a complex model in 
which the function of either Snf1 or Slt2 is only required when their respective degron is present. If correct such a model would predict that the degron impeaches degradation when not phosphorylated. Moreover, these studies predict independent roles for these two signaling pathways that ultimately direct in the same outcome of Med13 degradation.

\section{DISCUSSION}

Our previous work has shown that nuclear release of the yeast and mammalian cyclin $C$ predisposes cells to initiate PCD following stress $[7,8]$. In $S$. cerevisiae, this nuclear release requires the destruction of Med13 [27], mediated by the E3 ligase complex SCF ${ }^{\mathrm{Gr} 1}$, which requires SIt2 and Cdk8 activity [9]. In this current work, we provide evidence that Sak1 activated Snf1 is also required for $\mathrm{H}_{2} \mathrm{O}_{2}$ induced Med13 degradation and cyclin $\mathrm{C}$ nuclear release. In the absence of this kinase, Med13 degradation following $\mathrm{H}_{2} \mathrm{O}_{2}$ stress is inhibited and cyclin $\mathrm{C}$ remains predominantly nuclear. Consistent with this model, we showed that Snf1 is required for the degradation of the degron ${ }^{571-650}$. Paradoxically, deletion of this degron did not prevent $\mathrm{H}_{2} \mathrm{O}_{2}$ induced destruction of Med13. Instead, this mutant exhibited $\mathrm{H}_{2} \mathrm{O}_{2}$ induced Med13 degradation and cyclin $\mathrm{C}$ nuclear release. Intriguingly, deletion of the Slt2-resonsive degron (Med13 ${ }^{742-844}$ ) also did not protect Med13 from $\mathrm{H}_{2} \mathrm{O}_{2}$ induced degradation, although the protein was slightly more stable than wild type. Taken together, this study indicates that Slt2 and Snf1 pathways cooperate to trigger Med13 destruction. The use of two required pathways may help insure the proper signals are in place to target Med13.

To accommodate these two results, the following model that best fits the data is proposed (outlined in Fig. 8C). In unstressed cells the IDR of Med13, which encompasses both degrons, is protected from SCF ${ }^{\text {Grr } 1}$ activity (depicted by red circle in Fig. $8 \mathrm{C}$ ) by an unknown mechanism. Following $\mathrm{H}_{2} \mathrm{O}_{2}$ stress two events happen, the hierarchy of which is unknown. The protection is lost (depicted by green circle in Fig. 8C) and activated Snf1 and SIt2 phosphorylate their respective degrons, triggering $\mathrm{SCF}^{\mathrm{Gr} 1}$ mediated degradation of Med13. Although we currently favor the hypothesis that Snf1 directly phosphorylates Med13, we could not definitively exclude the possibility that Snf1 may promote Med13 phosphorylation indirectly via an intermediary kinase. That being said, the model presented in Fig. $8 \mathrm{C}$ could accommodate this possibility. More importantly however, the model supports the observation that both the AMPK and MAPK pathways act independently of each other (Fig. $4)$, and are required for Med13 degradation. However, in the absence of either the Snf1 or Slt2 degron, this protection is lost, allowing $\mathrm{SCF}^{\mathrm{Grr} 1}$ to recognize either activated degron. This model also accounts for the observation that when either degron is expressed in isolation, it requires its respective kinase to render it recognizable by $\mathrm{SCF}^{\mathrm{Grr} 1}$.

If this model is correct, then how could this region be protected from AMPK and MAPK activity in unstressed cells? One strong possibility could be connected to the fact that both degrons lie within the very large IDR of Med13 (Fig. 2A). IDR's are known to endow proteins with highly
A.

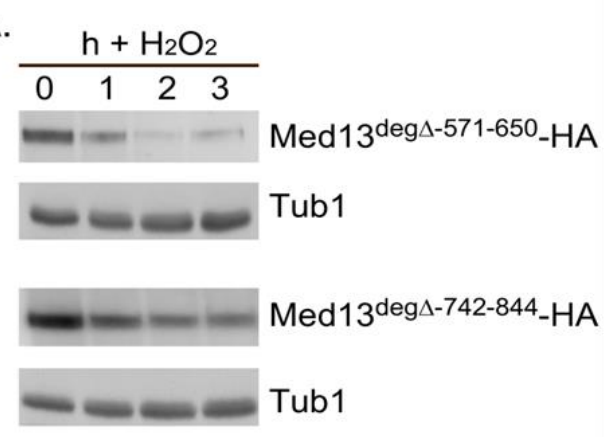

B.

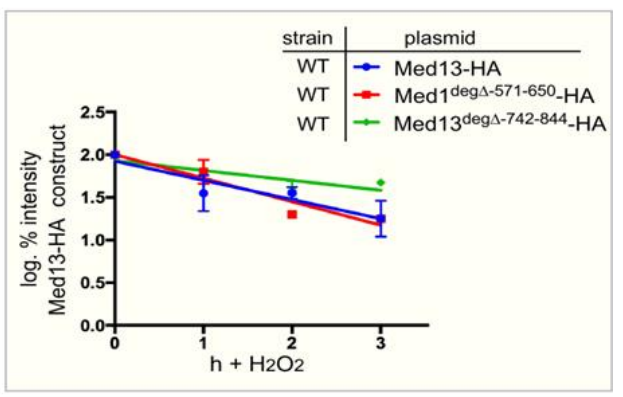

C.

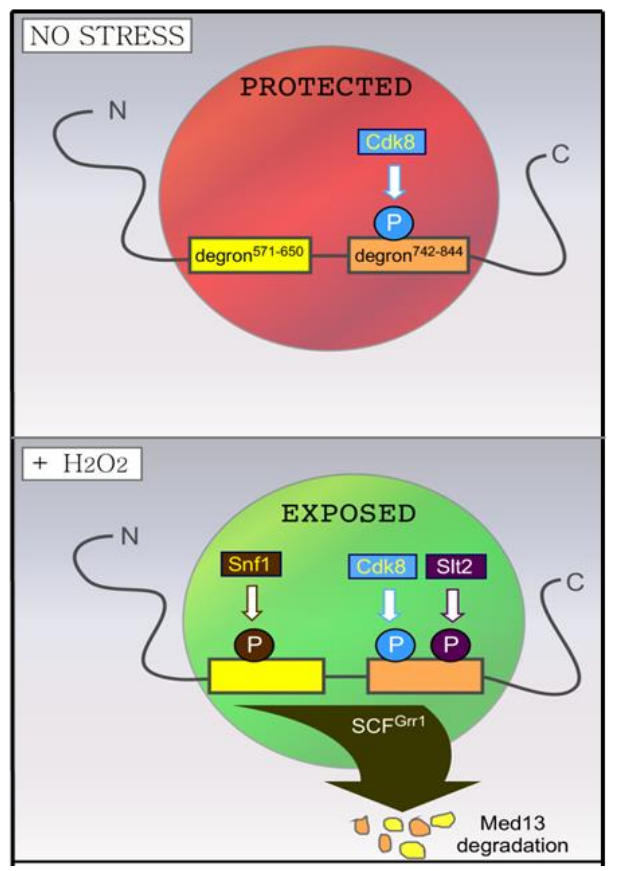

FIGURE 8: Either Med13 degron is sufficient for Med13 degradation. (A)

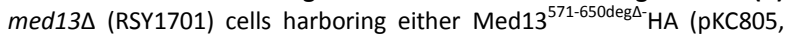
upper panels) or Med13 ${ }^{742-844 d e g \triangle}$ - HA plasmids (pKC814, lower panels) were treated with $0.4 \mathrm{mM} \mathrm{H}_{2} \mathrm{O}_{2}$ for the timepoints indicated and Med13 ${ }^{\operatorname{deg} \Delta-} \mathrm{HA}$ levels analyzed by Western blot. Tub1 levels were used as a loading control. (B) Degradation kinetics of the results shown in (A). Values represent averages \pm SD from a total of at least two Western blots from independent experiments. For clarity, the degradation kinetics of wild-type Med13-HA from previous experiments was included. (C) Model depicting how two $\mathrm{SCF}^{\mathrm{Grr} 1}$ phospho-degrons mediate the destruction of Med13 following $\mathrm{H}_{2} \mathrm{O}_{2}$ stress. In unstressed cells cyclin C-Cdk8 phosphorylates degron ${ }^{742-844}$ [9] but both degrons are protected by an unknown mechanism from Snf1 and Slt2 kinase activity (depicted by the red circle). Following $\mathrm{H}_{2} \mathrm{O}_{2}$ stress Snf1 and SIt2 are activated and permitted access to the now exposed degrons. This results in $\mathrm{SCF}^{\mathrm{Grr} 1}$ mediated degradation of Med13 and cyclin C nuclear release (not shown). 
malleable structures that undergo disorder-to-order transitions [65]. It has also been proposed that IDR's can have different binding partners that transiently associate [66]. In some cases, this can lead to proteins binding the same region that possess unrelated, or even opposite functions [67]. Thus, proteins that contain IDR's are frequently involved in signaling as they can easily change their conformational state in response to changing environmental conditions. Taken together, it is feasible to propose that in unstressed cells, the IDR of Med13 is in one conformational state that associates with an unknown protein, conferring protection to this region. Upon stress, the confirmation changes and the degron becomes exposed. This model is also consistent with the observation that IDR's are notorious for being regulated by multiple kinases $[64,68]$. This has led to the idea that IDR's and multiple phosphorylation events together provide structural variability [69], resulting in ultra-sensitive molecular switches that are triggered at a threshold level of phosphorylation. Thus, our results suggest a model in which Med13 degradation is regulated by three types of different kinases, a cyclin dependent kinase, a MAPK and an AMPK.

Lastly, here we show that Snf1 phosphorylates Med13, either directly or by an intermediary kinase, as well as associating with the CKM before stress (Fig. 5D). These results are consistent with a growing number of papers that have shown that a sub-population of the Snf1-Gal3 isoform is present in the nucleus under normal conditions $[52,60$, 70], as well as enriched in the nucleus upon glucose starvation [34-36]. In addition, Sak1 is needed for Snf1 nuclear localization [71]. In support of this model, Snf1, Gal83 and Sak1 localize to the SUC2 promotor under non-starvation conditions [52]. This promotor is also negatively regulated by the CKM [72]. Repression is relieved by Snf1 mediated phosphorylation of two proteins known to repress SUC2 expression, the DNA binding protein Mig1 [73] and the glucose kinase Hxk2 $[52,74]$, causing them to be released into the cytoplasm $[75,76]$. Likewise, carbon starvation results in the degradation of cyclin C [2], one event that occurs in the cytoplasm [4]. Surprisingly, we found that although Sak1 is needed for Med13 destruction following $\mathrm{H}_{2} \mathrm{O}_{2}$ stress, deletion of Gal83 has no effect (Fig. 3A and S2A). However, deletion of all three $\beta$-subunits does inhibit Med13 degradation. This would suggest that in the absence of Gal83, either Sip1 or Sip2 are able to activate nuclear Snf1. However, the Snf1-Sip1 and Snf1-Sip2 isoforms have not been reported to be nuclear, dispersing either to the vacuolar membrane (Sip1) or remaining cytoplasmic following carbon deprivation (Sip2) [34-36, 77]. Further studies need to be executed to address if Sip1 or Sip2 can translocate into the nucleus in the absence of Gal83. Intriguingly, just recently the Mitochondrial Voltage-Dependent Anion Channel Protein Por1 (yVDAC1) has been shown to enhance Snf1 nuclear enrichment by promoting the nuclear enrichment of Gal83 [70]. This unexpected finding serves to emphasize that there is still much to learn about the role Snf1 kinase plays in response to changing environmental conditions.

\section{MATERIALS AND METHODS}

\section{Yeast strains and plasmids}

All strains used in this study are listed in Table S1. Most experiments were performed in the S. cerevisiae W303 strain [78] and are listed in Table S1. Exceptions to this are the sak1 $\Delta$

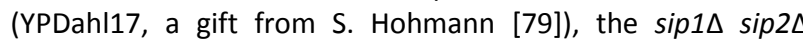

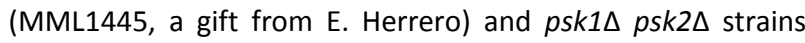

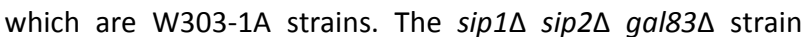
(MSY557, a gift from M. Schmidt [80]) is an S288c strain. Finally, the $\mathrm{Y} 2 \mathrm{H}$ assays were performed in PJ69-4a [40] that was obtained from the Yeast Resource center, a gift from S. Fields. In accordance with the Mediator nomenclature unification effort [81], we use CNC1 and CDK8 gene designations for cyclin C (SSN8/UME3/SRB11) and Cdk8 (SSN3/UME5/SRB10)

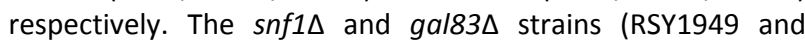
RSY2080 respectively) were constructed using gene replacement methodology as described [82]. The sak1D (RSY1976) was a gift from S. Hohmann [79]. All cells were grown at $30^{\circ} \mathrm{C}$.

All plasmids used in this study are listed in Table S2. The wild-type epitope tagged plasmids pKC801, pKC803 (MED13-

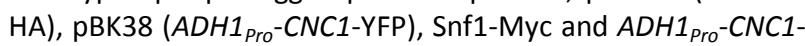
MYC (pKC337) are functional and have been previously described $[1,4,5,9,83,84]$. All other plasmids were constructed using PCR cloning techniques and details are available upon request. In short, all constructs were amplified from plasmid DNA using Phusion Taq (Thermo), digested using Thermo fast digest restriction enzymes and ligated using Thermo fast ligase into their respective vectors. Site directed mutagenesis (New England Bio-Labs Q5) was used to create plasmids harboring amino acid mutations and the change was confirmed by sequencing (Eurofins Genomics). The MED13 Y2H plasmids were constructed by PCR cloning regions of Med13 in frame with the Gal4 activating domain of pACT2. The NLS-Med13 fusion constructs were made by first creating a backbone vector (pNLS-HA) that contains the SV40 nuclear localization sequence (NLS) in frame with a single HA epitope tag under the control of the $A D H 1$ promotor. PCR-cloning was then used to place fragments of Med13 in frame with NLS. All in frame fusion proteins were verified by sequence analysis. Other plasmids that were used in this study that have been previously described.

\section{Cell growth}

Yeast cells were grown in either rich, non-selective medium (YPDA) or synthetic minimal medium (SC) allowing plasmid selection as previously described [1]. For all experiments, the cells were grown to mid-log phase $\left(\sim 6 \times 10^{6}\right.$ cells $\left./ \mathrm{ml}\right)$ before treatment with low concentrations of $0.4 \mathrm{mM} \mathrm{H}_{2} \mathrm{O}_{2}$ as previously described [5]. $25 \mathrm{ml}$ of cells were collected per timepoint, washed in water, then the pellet flash frozen in liquid nitrogen. Yeast two hybrid experiments were executed as described [41]. $E$. coli cells were grown in LB medium with selective antibiotics. For the kinase assays cells were initially grown in SD-Ura (1.7 g Yeast Nitrogen Base, $5 \mathrm{~g}$ Ammonium Sulfate, $20 \mathrm{~g}$ Dextrose per liter), overnight, diluted 1:100-fold into $500 \mathrm{ml}$ of SD-Ura, and grown for 10-12 h. Thereafter the cells were pelleted, and resuspended in $500 \mathrm{ml}$ SGal-Ura (1.7 g Yeast Nitrogen Base, 5 g Ammonium Sulfate, $20 \mathrm{~g}$ Galactose per liter)

\section{Western blot analysis and co-immunoprecipitation}

Tagged full length Med13-HA constructs were detected by using $\mathrm{NaOH}$ lysis of cell pellets exactly as described in [9]. To 
detect Med13-HA, 1 in 5000 dilutions of anti-HA antibodies (Abcam) were used. The co-immunoprecipitation analysis was performed essentially as described [85]. Anti-alpha tubulin antibodies (12G10) were obtained from the Developmental Studies Hybridoma Bank, University of lowa. Western blot signals were detected using either goat anti-mouse or goat anti-rabbit secondary antibodies conjugated to alkaline phosphatase (Sigma) and the CDP-Star chemiluminescence kit (Thermo). Signals were quantitated by CCD camera imaging (Kodak) and standardized to the loading control. All degradation assays were performed two or three times. SEM's were generated for each point (error bars are indicated on the graphs) and the data analyzed using linear regression analysis using GraphPad Prism 7 program.

\section{Snf1 activation and kinase assays}

The Snf1 activation assays were executed as follows. Cells were grown to mid-log phase and treated with $0.4 \mathrm{mM} \mathrm{H}_{2} \mathrm{O}_{2}$ for the times indicated They were immediately boiled for 3 minutes and pellets frozen using liquid nitrogen. Protein extracts were made using the $\mathrm{NaOH}$ method described in [9] and analyzed by SDS-PAGE and Western blotting. Anti-phosphoThr172-AMPK (Cell Signaling Technology; Cat. No. 2531) was used to detect phosphorylated Snf1 and polyhistidine antibody H1029 (Sigma-Aldrich) to detect Snf1. This is possible as Snf1 ORF contains 13 contiguous histidine residues at its $N$ terminus.

The in vitro kinase assays were executed as follows. Wildtype or $c d k 8 \Delta$ cells harboring either myc-tagged Snf1 or Snf1 kinase dead (K84R) under the control of the GAL1-10 promotor, were first grown in SD-Ura followed by SGal-Ura as described above and then resuspended in lysis buffer $(20 \mathrm{mM}$ HEPES, $10 \mathrm{mM} \mathrm{KCl}, 1 \mathrm{mM}$ EDTA, $1 \mathrm{mM}$ ethylene glycol tetraacetic acid (EGTA), $50 \mathrm{mM} \mathrm{NaCl}, 10 \%$ glycerol, $1 \mathrm{mM} \beta$ mercaptoethanol, Pierce $^{\mathrm{TM}}$ Protease Inhibitor Tablets, $\mathrm{pH} 7.4$ with phosphatase inhibitors). Resuspended cultures were lysed using a Microfluidics M-110P homogenizer (Microfluidics) and cell debris removed by centrifugation at $12,000 \times \mathrm{g}$ for $30 \mathrm{~min}$. Supernatants were incubated with $5-10 \mu \mathrm{l}$ of Mycconjugated magnetic beads (Cell Signaling) for $2-3 \mathrm{~h}$ at $4^{\circ} \mathrm{C}$. Beads were separated using magnetic force and washed four times with $1 \mathrm{ml}$ of lysis buffer lacking protease inhibitors. Beads containing Myc-tagged proteins were used directly for in vitro kinase assays without eluting. GST-Med13 $3^{571-6505608 \mathrm{~A}}$ was purified from E. coli BL21 DE3 strain as previously described [9] and incubated with the Snf1 immunoprecipitates in $30 \mu \mathrm{l}$ of reaction buffer containing $1 \mathrm{X}$ Snf1 kinase buffer (50 $\mathrm{mM}$ Tris- $\mathrm{HCl}, 10 \mathrm{mM} \mathrm{MgCl}, 1 \mathrm{mM}$ dithiothreitol (DTT), $\mathrm{pH} 7.5$,

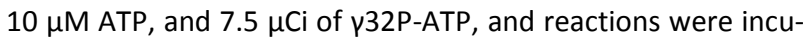
bated for $35 \mathrm{~min}$ at $30^{\circ} \mathrm{C}$. Kinase assays were stopped by the addition of SDS-PAGE sample buffer, analyzed by SDS-PAGE, stained with coommassie (30 $\mathrm{min})$, destained for $2 \mathrm{~h}$, dried and exposed to film.

\section{REFERENCES}

1. Cooper KF, Mallory MJ, Smith JB, Strich R (1997). Stress and developmental regulation of the yeast C-type cyclin Ume3p

\section{Fluorescence Microscopy}

Cyclin C-YFP subcellular localization and mitochondrial morphology were monitored as described previously [4, 7]. For all experiments, the cells were grown to mid-log $\left(6 \times 10^{6}\right.$ cells $\left./ \mathrm{ml}\right)$, treated with $0.4 \mathrm{mM} \mathrm{H}_{2} \mathrm{O}_{2}$ for the timepoints indicated, then analyzed by fluorescence microscopy. Cyclin C-YFP release analysis was performed on cells stained with DAPI in mounting medium $(10 \mathrm{mg} / \mathrm{ml}$ p-phenylenediamine, $50 \mathrm{ng} / \mathrm{ml} \mathrm{4',6-}$ diamidino-2-phenylindole, Molecular Probes) to visualize nuclei and prevent photo bleaching. Images were obtained using a Nikon microscope (model E800) with a 100X objective with 1.2X camera magnification (Plan Fluor Oil, NA 1.3) and a CCD camera (Hamamatsu model C4742). Data were collected using NIS software and processed using Image Pro software. All images of individual cells were optically sectioned $(0.2 \mu \mathrm{M}$ slices at $0.3 \mu \mathrm{M}$ spacing) deconvolved and the slices were collapsed to visualize the entire fluorescent signal within the cell. Cyclin C-YFP foci were scored as being cytoplasmic when 3 or more foci were observed outside of the nucleus. Mitochondrial fission assays were performed on live cells as described [7]. In brief, mitochondrial fission was scored positive if no reticular mitochondria were observed that transversed half the cell diameter. Fusion was scored when cells exhibited one or more reticular mitochondria the diameter of the cell. Fission and fusion was scored for 200 cells from three independent isolates. Statistical analysis was performed using the Student's T-test.

\section{ACKNOWLEDGMENTS}

We thank. S. Fields, S. Hohmann, E. Herrero, J. Nunnari, M. Schmidt and M. Solomon for strains and plasmids. We thank R. Strich for critical reading of this manuscript. This work was supported by grants from the National Institutes of Health awarded to K.F.C. (GM113196), and J.G (GM100376). The yeast two-hybrid strain was made by work supported by NIH grant P41 RR11823 awarded to T. N. Davis.

\section{CONFLICT OF INTEREST}

The authors declare no conflict of interest.

\section{COPYRIGHT}

(C) 2018 Willis et al. This is an open-access article released under the terms of the Creative Commons Attribution (CC BY) license, which allows the unrestricted use, distribution, and reproduction in any medium, provided the original author and source are acknowledged.

Please cite this article as: Stephen D. Willis, David C. Stieg, Kai Li Ong, Ravina Shah, Alexandra K. Strich, Julianne H. Grose and Katrina F. Cooper (2018). Snf1 cooperates with the CWI MAPK pathway to mediate the degradation of Med13 following oxidative stress. Microbial Cell 5(8): 357-370. doi: 10.15698/mic2018.08.641

(Srb11p/Ssn8p). EMBO J 16(15): 4665-4675. doi: 10.1093/emboj/16.15.4665 
2. Cooper KF, Mallory MJ, Strich R (1999). Oxidative stress-induced destruction of the yeast C-type cyclin Ume3p requires phosphatidylinositol-specific phospholipase $\mathrm{C}$ and the $26 \mathrm{~S}$ proteasome. Mol Cell Biol 19(5): 3338-3348. doi 10.1128/mcb.19.5.3338

3. Krasley E, Cooper KF, Mallory MJ, Dunbrack R, Strich R (2006). Regulation of the oxidative stress response through Slt2p-dependent destruction of cyclin C in Saccharomyces cerevisiae. Genetics 172(3) 1477-1486. doi: 10.1534/genetics.105.052266

4. Cooper KF, Scarnati MS, Krasley E, Mallory MJ, Jin C, Law MJ, Strich $R$ (2012). Oxidative-stress-induced nuclear to cytoplasmic relocalization is required for Not4-dependent cyclin C destruction. J Cell Sci 125(Pt 4): 1015-1026. doi: 10.1242/jcs.096479

5. Jin C, Parshin AV, Daly I, Strich R, Cooper KF (2013). The cell wall sensors Mtl1, Wsc1, and Mid2 are required for stress-induced nuclear to cytoplasmic translocation of cyclin C and programmed cell death in yeast. Oxid Med Cell Longev 2013(320823. doi: 10.1155/2013/320823

6. Jin C, Strich R, Cooper KF (2014). Slt2p phosphorylation induces cyclin $C$ nuclear-to-cytoplasmic translocation in response to oxidative stress. Mol Biol Cell 25(8): 1396-1407. doi: 10.1091/mbc.E13-09-0550

7. Cooper KF, Khakhina S, Kim SK, Strich R (2014). Stress-induced nuclear-to-cytoplasmic translocation of cyclin $\mathrm{C}$ promotes mitochondrial fission in yeast. Dev Cell 28(2): 161-173. doi: 10.1016/j.devcel.2013.12.009

8. Wang K, Yan R, Cooper KF, Strich R (2015). Cyclin C mediates stressinduced mitochondrial fission and apoptosis. Mol Biol Cell 26(6): 1030-1043. doi: 10.1091/mbc.E14-08-1315

9. Stieg DC, Willis SD, Ganesan V, Ong KL, Scuorzo J, Song M, Grose J, Strich R, Cooper KF (2018). A complex molecular switch directs stressinduced cyclin C nuclear release through SCF(Grr1)-mediated degradation of Med13. Mol Biol Cell 29(3): 363-375. doi: 10.1091/mbc.E17-08-0493

10. Bourbon HM (2008). Comparative genomics supports a deep evolutionary origin for the large, four-module transcriptional mediator complex. Nucleic Acids Res 36(12): 3993-4008. doi: 10.1093/nar/gkn349

11. Yin JW, Wang G (2014). The Mediator complex: a master coordinator of transcription and cell lineage development. Development 141(5): 977-987. doi: 10.1242/dev.098392

12. Allen BL, Taatjes DJ (2015). The Mediator complex: a central integrator of transcription. Nat Rev Mol Cell Biol 16(3): 155-166. doi 10.1038/nrm3951

13. Surosky RT, Strich R, Esposito RE (1994). The yeast UME5 gene regulates the stability of meiotic mRNAs in response to glucose. Mol. Cell. Biol. 14(3446-3458. doi: 10.1128/MCB.14.5.3446

14. Holstege FC, Jennings EG, Wyrick JJ, Lee TI, Hengartner CJ, Green MR, Golub TR, Lander ES, Young RA (1998). Dissecting the regulatory circuitry of a eukaryotic genome. Cell 95(5): 717-728. doi: 10.1016/S0092-8674(00)81641-4

15. Chi Y, Huddleston MJ, Zhang X, Young RA, Annan RS, Carr SA Deshaies RJ (2001). Negative regulation of Gcn4 and Msn2 transcription factors by Srb10 cyclin-dependent kinase. Genes Dev 15(9): 1078-1092. doi: 10.1101/gad.867501

16. van de Peppel J, Kettelarij N, van Bakel H, Kockelkorn TT, van Leenen D, Holstege FC (2005). Mediator expression profiling epistasis reveals a signal transduction pathway with antagonistic submodules and highly specific downstream targets. Mol Cell 19(4): 511-522. doi: 10.1016/j.molcel.2005.06.033

17. Jendretzki A, Wittland J, Wilk S, Straede A, Heinisch JJ (2011). How do I begin? Sensing extracellular stress to maintain yeast cell wall integrity. Eur J Cell Biol 90(9): 740-744. doi: 10.1016/j.ejcb.2011.04.006

18. Levin DE (2011). Regulation of cell wall biogenesis in Saccharomyces cerevisiae: the cell wall integrity signaling pathway. Genetics 189(4): 1145-1175. doi: 10.1534/genetics.111.128264

19. Heinisch JJ, Rodicio R (2018). Protein kinase C in fungi-more than just cell wall integrity. FEMS Microbiol Rev 42(1). doi: 10.1093/femsre/fux051

20. Lee KS, Irie K, Gotoh $Y$, Watanabe $Y$, Araki H, Nishida E, Matsumoto $K$, Levin DE (1993). A yeast mitogen-activated protein kinase homolog (Mpk1p) mediates signalling by protein kinase C. Mol Cell Biol 13(5): 3067-3075. doi: 10.1128/MCB.13.5.3067

21. Watanabe Y, Takaesu G, Hagiwara M, Irie K, Matsumoto K (1997). Characterization of a serum response factor-like protein in Saccharomyces cerevisiae, RIm1, which has transcriptional activity regulated by the Mpk1 (Slt2) mitogen-activated protein kinase pathway. Mol Cell Biol 17(5): 2615-2623. doi: 10.1128/MCB.17.5.2615

22. Jung US, Sobering AK, Romeo MJ, Levin DE (2002). Regulation of the yeast RIm1 transcription factor by the Mpk1 cell wall integrity MAP kinase. Mol Microbiol 46(3): 781-789. doi: 10.1046/j.13652958.2002.03198.x

23. Kim KY, Truman AW, Levin DE (2008). Yeast Mpk1 mitogenactivated protein kinase activates transcription through Swi4/Swi6 by a noncatalytic mechanism that requires upstream signal. Mol Cell Biol 28(8): 2579-2589. doi: 10.1128/MCB.01795-07

24. Kim KY, Levin DE (2011). Mpk1 MAPK association with the Paf1 complex blocks Sen1-mediated premature transcription termination. Cell 144(5): 745-756. doi: 10.1016/j.cell.2011.01.034

25. Yurko N, Liu X, Yamazaki T, Hoque M, Tian B, Manley JL (2017). MPK1/SLT2 Links Multiple Stress Responses with Gene Expression in Budding Yeast by Phosphorylating Tyr1 of the RNAP II CTD. Mol Cell 68(5): 913-925 e913. doi: 10.1016/j.molcel.2017.11.020

26. Shah N, Maqbool MA, Yahia Y, El Aabidine AZ, Esnault C, Forne I, Decker TM, Martin D, Schuller R, Krebs S, Blum H, Imhof A, Eick D, Andrau JC (2018). Tyrosine-1 of RNA Polymerase II CTD Controls Global Termination of Gene Transcription in Mammals. Mol Cell 69(1): 48-61 e46. doi: 10.1016/j.molcel.2017.12.009

27. Khakhina S, Cooper KF, Strich R (2014). Med13p prevents mitochondrial fission and programmed cell death in yeast through nuclear retention of cyclin C. Mol Biol Cell 25(18): 2807-2816. doi: 10.1091/mbc.E14-05-0953

28. Ang XL, Wade Harper J (2005). SCF-mediated protein degradation and cell cycle control. Oncogene 24(17): 2860-2870. doi: 10.1038/sj.onc.1208614

29. Dyson HJ, Wright PE (2005). Intrinsically unstructured proteins and their functions. Nat Rev Mol Cell Biol 6(3): 197-208. doi: $10.1038 / \mathrm{nrm} 1589$

30. Fuxreiter M, Toth-Petroczy A, Kraut DA, Matouschek A, Lim RY, Xue B, Kurgan L, Uversky VN (2014). Disordered proteinaceous machines. Chem Rev 114(13): 6806-6843. doi: 10.1021/cr4007329

31. Yachdav G, Kloppmann E, Kajan L, Hecht M, Goldberg T, Hamp T, Honigschmid $P$, Schafferhans $A$, Roos $M$, Bernhofer $M$, Richter $L$, Ashkenazy H, Punta M, Schlessinger A, Bromberg $Y$, Schneider R, Vriend G, Sander C, Ben-Tal N, Rost B (2014). PredictProtein--an open resource for online prediction of protein structural and functional features. Nucleic Acids Res 42(Web Server issue): W337-343. doi: 10.1093/nar/gku366

32. Hedbacker K, Carlson M (2008). SNF1/AMPK pathways in yeast. Front Biosci 13(2408-2420. doi: 10.2741/2854 
33. Hong SP, Carlson M (2007). Regulation of snf1 protein kinase in response to environmental stress. J Biol Chem 282(23): 16838-16845. doi: 10.1074/jbc.M700146200

34. Vincent O, Townley R, Kuchin S, Carlson M (2001). Subcellular localization of the Snf1 kinase is regulated by specific beta subunits and a novel glucose signaling mechanism. Genes Dev 15(9): 11041114. doi: $10.1101 / \operatorname{gad} .879301$

35. Hedbacker K, Hong SP, Carlson M (2004). Pak1 protein kinase regulates activation and nuclear localization of Snf1-Gal83 protein kinase. Mol Cell Biol 24(18): 8255-8263. doi: 10.1128/MCB.24.18.8255-8263.2004

36. Hedbacker K, Carlson M (2006). Regulation of the nucleocytoplasmic distribution of Snf1-Gal83 protein kinase. Eukaryot Cell 5(12): 1950-1956. doi: 10.1128/EC.00256-06

37. McCartney RR, Schmidt MC (2001). Regulation of Snf1 kinase. Activation requires phosphorylation of threonine 210 by an upstream kinase as well as a distinct step mediated by the Snf4 subunit. J Biol Chem 276(39): 36460-36466. doi: 10.1074/jbc.M104418200

38. Nath N, McCartney RR, Schmidt MC (2002). Purification and characterization of Snf1 kinase complexes containing a defined Beta subunit composition. J Biol Chem 277(52): 50403-50408. doi: 10.1074/jbc.M207058200

39. Sutherland CM, Hawley SA, McCartney RR, Leech A, Stark MJ, Schmidt MC, Hardie DG (2003). Elm1p is one of three upstream kinases for the Saccharomyces cerevisiae SNF1 complex. Curr Biol 13(15): 1299-1305. doi: 10.1016/S0960-9822(03)00459-7

40. James P, Halladay J, Craig EA (1996). Genomic libraries and a host strain designed for highly efficient two-hybrid selection in yeast. Genetics 144(4): 1425-1436. PMID: 8978031

41. Wang R, Solomon MJ (2012). Identification of She3 as an SCF(Grr1) substrate in budding yeast. PLoS One 7(10): e48020. doi: 10.1371/journal.pone.0048020

42. Gonzalez D, Hamidi N, Del Sol R, Benschop JJ, Nancy T, Li C, Francis L, Tzouros M, Krijgsveld J, Holstege FC, Conlan RS (2014). Suppression of Mediator is regulated by Cdk8-dependent Grr1 turnover of the Med3 coactivator. Proc Natl Acad Sci U S A 111(7): 2500-2505. doi: 10.1073/pnas.1307525111

43. Madeo F, Frohlich E, Ligr M, Grey M, Sigrist SJ, Wolf DH, Frohlich KU (1999). Oxygen stress: a regulator of apoptosis in yeast. J Cell Biol 145(4): 757-767. doi: 10.1083/jcb.145.4.757

44. Carmona-Gutierrez D, Eisenberg T, Buttner S, Meisinger C, Kroemer G, Madeo F (2010). Apoptosis in yeast: triggers, pathways, subroutines. Cell Death Differ 17(5): 763-773. doi: 10.1038/cdd.2009.219

45. Galluzzi L, Vanden Berghe T, Vanlangenakker N, Buettner S, Eisenberg T, Vandenabeele P, Madeo F, Kroemer G (2011). Programmed necrosis from molecules to health and disease. Int Rev Cell Mol Biol 289(1-35. doi: 10.1016/B978-0-12-386039-2.00001-8

46. Rutter J, Michnoff $\mathrm{CH}$, Harper SM, Gardner $\mathrm{KH}$, McKnight SL (2001). PAS kinase: an evolutionarily conserved PAS domain-regulated serine/threonine kinase. Proc Natl Acad Sci U S A 98(16): 8991-8996. doi: $10.1073 /$ pnas.161284798

47. DeMille D, Bikman BT, Mathis AD, Prince JT, Mackay JT, Sowa SW, Hall TD, Grose JH (2014). A comprehensive protein-protein interactome for yeast PAS kinase 1 reveals direct inhibition of respiration through the phosphorylation of Cbf1. Mol Biol Cell 25(14): 2199-2215. doi: 10.1091/mbc.E13-10-0631

48. Grose JH, Smith TL, Sabic H, Rutter J (2007). Yeast PAS kinase coordinates glucose partitioning in response to metabolic and cell integrity signaling. EMBO J 26(23): 4824-4830. doi: 10.1038/sj.emboj.7601914

49. DeMille D, Badal BD, Evans JB, Mathis AD, Anderson JF, Grose JH (2015). PAS kinase is activated by direct SNF1-dependent phosphorylation and mediates inhibition of TORC1 through the phosphorylation and activation of Pbp1. Mol Biol Cell 26(3): 569-582. doi: 10.1091/mbc.E14-06-1088

50. Lubitz T, Welkenhuysen N, Shashkova S, Bendrioua L, Hohmann S, Klipp E, Krantz M (2015). Network reconstruction and validation of the Snf1/AMPK pathway in baker's yeast based on a comprehensive literature review. NPJ Syst Biol Appl 1(15007. doi 10.1038/npjsba.2015.7

51. Estruch F, Treitel MA, Yang X, Carlson M (1992). N-terminal mutations modulate yeast SNF1 protein kinase function. Genetics 132(3): 639-650. PMID: 1468623

52. Vega M, Riera A, Fernandez-Cid A, Herrero P, Moreno F (2016). Hexokinase 2 Is an Intracellular Glucose Sensor of Yeast Cells That Maintains the Structure and Activity of Mig1 Protein Repressor Complex. J Biol Chem 291(14): 7267-7285. doi: 10.1074/jbc.M115.711408

53. Shashkova S, Welkenhuysen N, Hohmann S (2015). Molecular communication: crosstalk between the Snf1 and other signaling pathways. FEMS Yeast Res 15(4): fov026. doi: 10.1093/femsyr/fov026

54. Backhaus K, Rippert D, Heilmann CJ, Sorgo AG, de Koster CG, Klis FM, Rodicio R, Heinisch JJ (2013). Mutations in SNF1 complex genes affect yeast cell wall strength. Eur J Cell Biol 92(12): 383-395. doi: 10.1016/j.ejcb.2014.01.001

55. Benanti JA, Cheung SK, Brady MC, Toczyski DP (2007). A proteomic screen reveals SCFGrr1 targets that regulate the glycolyticgluconeogenic switch. Nat Cell Biol 9(10): 1184-1191. doi: $10.1038 /$ ncb1639

56. Albuquerque CP, Smolka MB, Payne SH, Bafna V, Eng J, Zhou H (2008). A multidimensional chromatography technology for in-depth phosphoproteome analysis. Mol Cell Proteomics 7(7): 1389-1396. doi: 10.1074/mcp.M700468-MCP200

57. Kanshin E, Giguere S, Cheng J, Tyers MD, Thibault P (2017). Machine learning of global phosphoproteomic profiles enables discrimination of direct versus indirect kinase substrates. Mol Cell Proteomics. doi: 10.1074/mcp.M116.066233

58. Dale S, Wilson WA, Edelman AM, Hardie DG (1995). Similar substrate recognition motifs for mammalian AMP-activated protein kinase, higher plant HMG-CoA reductase kinase-A, yeast SNF1, and mammalian calmodulin-dependent protein kinase I. FEBS Lett 361(2 3): 191-195. doi: 10.1016/0014-5793(95)00172-6

59. Mok J, Kim PM, Lam HY, Piccirillo S, Zhou X, Jeschke GR, Sheridan DL, Parker SA, Desai V, Jwa M, Cameroni E, Niu H, Good M, Remenyi A Ma JL, Sheu YJ, Sassi HE, Sopko R, Chan CS, De Virgilio C, Hollingsworth NM, Lim WA, Stern DF, Stillman B, Andrews BJ, Gerstein MB, Snyder $M$, Turk BE (2010). Deciphering protein kinase specificity through large-scale analysis of yeast phosphorylation site motifs. Sci Signal 3(109): ra12. doi: 10.1126/scisignal.2000482

60. Kuchin S, Treich I, Carlson M (2000). A regulatory shortcut between the Snf1 protein kinase and RNA polymerase II holoenzyme. Proc Natl Acad Sci U S A 97(14): 7916-7920. doi: 10.1073/pnas.140109897

61. Chang YW, Howard SC, Herman PK (2004). The Ras/PKA signaling pathway directly targets the Srb9 protein, a component of the general RNA polymerase II transcription apparatus. Mol Cell 15(1): 107-116 doi: 10.1016/j.molcel.2004.05.021

62. Smith FC, Davies SP, Wilson WA, Carling D, Hardie DG (1999). The SNF1 kinase complex from Saccharomyces cerevisiae phosphorylates 
the transcriptional repressor protein Mig1p in vitro at four sites within or near regulatory domain 1. FEBS Lett 453(1-2): 219-223. doi: 10.1016/S0014-5793(99)00725-5

63. Nigg EA (1993). Cellular substrates of $\mathrm{p} 34(\mathrm{cdc} 2)$ and its companion cyclin-dependent kinases. Trends Cell Biol 3(9): 296-301. doi: 10.1016/0962-8924(93)90011-0

64. Wright PE, Dyson HJ (2015). Intrinsically disordered proteins in cellular signalling and regulation. Nat Rev Mol Cell Biol 16(1): 18-29. doi: $10.1038 / \mathrm{nrm} 3920$

65. Diella F, Haslam N, Chica C, Budd A, Michael S, Brown NP, Trave G, Gibson TJ (2008). Understanding eukaryotic linear motifs and their role in cell signaling and regulation. Front Biosci 13: 6580-6603. doi: $10.2741 / 3175$

66. Uversky VN (2011). Multitude of binding modes attainable by intrinsically disordered proteins: a portrait gallery of disorder-based complexes. Chem Soc Rev 40(3): 1623-1634. doi: 10.1039/c0cs00057d

67. Tompa $P$ (2005). The interplay between structure and function in intrinsically unstructured proteins. FEBS Lett 579(15): 3346-3354. doi: 10.1016/j.febslet.2005.03.072

68. Collins MO, Yu L, Campuzano I, Grant SG, Choudhary JS (2008). Phosphoproteomic analysis of the mouse brain cytosol reveals a predominance of protein phosphorylation in regions of intrinsic sequence disorder. Mol Cell Proteomics 7(7): 1331-1348. doi: 10.1074/mcp.M700564-MCP200

69. Trudeau T, Nassar R, Cumberworth A, Wong ET, Woollard G, Gsponer J (2013). Structure and intrinsic disorder in protein autoinhibition. Structure 21(3): 332-341. doi: 10.1016/j.str.2012.12.013

70. Shevade A, Strogolova V, Orlova M, Yeo CT, Kuchin S (2018). Mitochondrial Voltage-Dependent Anion Channel Protein Por1 Positively Regulates the Nuclear Localization of Saccharomyces cerevisiae AMP-Activated Protein Kinase. mSphere 3(1). doi: 10.1128/mSphere.00482-17

71. Elbing K, McCartney RR, Schmidt MC (2006). Purification and characterization of the three Snf1-activating kinases of Saccharomyces cerevisiae. Biochem J 393(Pt 3): 797-805. doi: 10.1042/BJ20051213

72. Vallier LG, Carlson M (1994). Synergistic release from glucose repression by mig1 and ssn mutations in Saccharomyces cerevisiae. Genetics 137(1): 49-54. PMID: 8056322

73. Treitel MA, Kuchin S, Carlson M (1998). Snf1 protein kinase regulates phosphorylation of the Mig1 repressor in Saccharomyces cerevisiae. Mol Cell Biol 18(11): 6273-6280. doi: 10.1128/mcb.18.11.6273

74. Rodriguez A, De La Cera T, Herrero P, Moreno F (2001). The hexokinase 2 protein regulates the expression of the GLK1, HXK1 and HXK2 genes of Saccharomyces cerevisiae. Biochem J 355(Pt 3): 625631. doi: 10.1042/bj3550625

75. De Vit MJ, Waddle JA, Johnston M (1997). Regulated nuclear translocation of the Mig1 glucose repressor. Mol Biol Cell 8(8): 16031618. doi: $10.1091 / \mathrm{mbc}$.8.8.1603

76. Fernandez-Garcia P, Pelaez R, Herrero P, Moreno F (2012). Phosphorylation of yeast hexokinase 2 regulates its nucleocytoplasmic shuttling. J Biol Chem 287(50): 42151-42164. doi: 10.1074/jbc.M112.401679
77. Hedbacker K, Townley R, Carlson M (2004). Cyclic AMP-dependent protein kinase regulates the subcellular localization of Snf1-Sip1 protein kinase. Mol Cell Biol 24(5): 1836-1843. doi: 10.1128/mcb.24.5.1836-1843.2004

78. Strich R, Slater MR, Esposito RE (1989). Identification of negative regulatory genes that govern the expression of early meiotic genes in yeast. Proc. Natl. Acad. Sci. USA 86(10018-10022. doi: 10.1073/pnas.86.24.10018

79. Ye T, Elbing K, Hohmann S (2008). The pathway by which the yeast protein kinase Snf1p controls acquisition of sodium tolerance is different from that mediating glucose regulation. Microbiology 154(Pt 9): 2814-2826. doi: 10.1099/mic.0.2008/020149-0

80. Shirra MK, McCartney RR, Zhang C, Shokat KM, Schmidt MC, Arndt KM (2008). A chemical genomics study identifies Snf1 as a repressor of GCN4 translation. J Biol Chem 283(51): 35889-35898. doi: 10.1074/jbc.M805325200

81. Bourbon HM, Aguilera A, Ansari AZ, Asturias FJ, Berk AJ, Bjorklund S, Blackwell TK, Borggrefe T, Carey M, Carlson M, Conaway JW, Conaway RC, Emmons SW, Fondell JD, Freedman LP, Fukasawa T, Gustafsson CM, Han M, He X, Herman PK, Hinnebusch AG, Holmberg $S$, Holstege FC, Jaehning JA, Kim YJ, Kuras L, Leutz A, Lis JT, Meisterernest M, Naar AM, et al. (2004). A Unified Nomenclature for Protein Subunits of Mediator Complexes Linking Transcriptional Regulators to RNA Polymerase II. Mol Cell 14(5): 553-557. doi: 10.1016/j.molcel.2004.05.011

82. Longtine MS, McKenzie A, 3rd, Demarini DJ, Shah NG, Wach A, Brachat A, Philippsen P, Pringle JR (1998). Additional modules for versatile and economical PCR-based gene deletion and modification in Saccharomyces cerevisiae. Yeast 14(10): 953-961. doi: 10.1002/(SICI)1097-0061(199807)14:10<953::AID-YEA293>3.0.CO;2-U

83. Simpson-Lavy KJ, Johnston M (2013). SUMOylation regulates the SNF1 protein kinase. Proc Natl Acad Sci U S A 110(43): 17432-17437. doi: 10.1073/pnas.1304839110

84. Strogolova V, Orlova M, Shevade A, Kuchin S (2012). Mitochondrial porin Por1 and its homolog Por2 contribute to the positive control of Snf1 protein kinase in Saccharomyces cerevisiae. Eukaryot Cell 11(12): 1568-1572. doi: 10.1128/EC.00127-12

85. Cooper KF, Strich R (1999). Functional analysis of the Ume3p/ Srb11p-RNA polymerase II holoenzyme interaction. Gene Expr 8(1): 43-57. PMID: 10543730

86. Cooper KF, Mallory MJ, Egeland DB, Jarnik M, Strich R (2000). Ama1p is a meiosis-specific regulator of the anaphase promoting complex/cyclosome in yeast. Proc Natl Acad Sci U S A 97(26): 1454814553. doi: 10.1073/pnas. 250351297

87. Perez-Sampietro M, Casas C, Herrero E (2013). The AMPK family member Snf1 protects Saccharomyces cerevisiae cells upon glutathione oxidation. PLoS One 8(3): e58283. doi: 10.1371/journal.pone.0058283

88. Van Criekinge W, Beyaert R (1999). Yeast Two-Hybrid: State of the Art. Biol Proced Online 2(1-38. doi: 10.1251/bpo16

89. Sikorski RS, Hieter P (1989). A system of shuttle vectors and yeast host strains designed for efficient manipulation of DNA in Saccharomyces cerevisiae. Genet. 122: 19-27. PMID: 2659436 